Saint Louis University School of Law Scholarship Commons

All Faculty Scholarship

2013

\title{
State Power to Define Jurisdiction
}

Samuel P. Jordan

Saint Louis University School of Law

Christopher Kennedy Bader

Saint Louis University School of Law

Follow this and additional works at: https://scholarship.law.slu.edu/faculty

Part of the Constitutional Law Commons

\section{Recommended Citation}

Jordan, Samuel P. and Bader, Christopher Kennedy, State Power to Define Jurisdiction (August 28, 2012). 47 Ga. L. Rev. 1161 (2013).

This Article is brought to you for free and open access by Scholarship Commons. It has been accepted for inclusion in All Faculty Scholarship by an authorized administrator of Scholarship Commons. For more information, please contact erika.cohn@slu.edu, ingah.daviscrawford@slu.edu. 


\section{State Power to Define JuRisdiction}

\section{Sam Jordan}

Christopher Bader

States should have much broader authority to decline jurisdiction over federal claims. The normative considerations supporting this doctrine of "reverse abstention" have been developed in previous work. But what of the Constitution? The traditional reading, reflected in existing precedent, asserts that the Supremacy Clause, Article III, and perhaps Article I operate together to create an inflexible obligation for state courts to hear federal claims. This reading is misguided. The Supremacy Clause contains no jurisdictional obligation of its own force, but only gives supreme effect to other validly enacted federal laws. And no other clause provides the authority to impose such an obligation on the states. Suggestions to the contrary are based on an overly cramped version of originalism that fails to account for the exigencies of constitutional compromise and ratification. 


\section{State Power to Define Jurisdiction}

Sam Jordan*

Christopher Bader $^{\dagger}$

\section{TABLE OF CONTENTS}

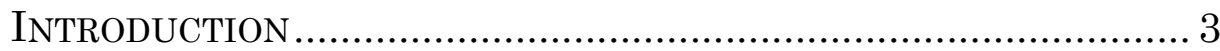

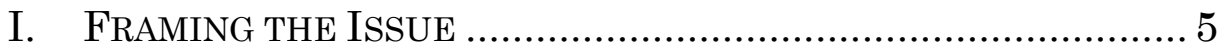

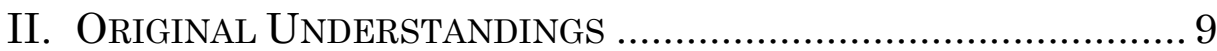

A. Article VI and Federal Supremacy ……........................ 10

1. The Convention ....................................................... 11

2. The Ratification Debates ......................................... 14

3. Early Congress...................................................... 16

4. The State Judges Clause ………………................. 19

B. Article III and Constitutional Necessity...................... 22

1. The Convention .......................................................... 23

2. The Ratification Debates .......................................... 25

3. Other Founding Sources .......................................... 27

C. Article I and Congressional Prerogative....................... 34

III. INDETERMINACY AND COMPROMISE .................................... 37

A. Originalism's Indeterminacy ........................................... 37

B. The Need for Compromise ............................................. 44

C. The Intentionalist Thesis Revisited............................... 46

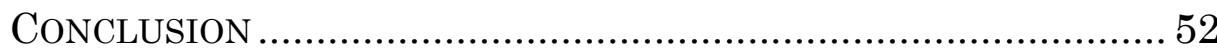

* Associate Professor of Law, Saint Louis University School of Law.

$\dagger$ J.D. Candidate, May 2013, Saint Louis University School of Law. Many thanks to James Pfander, Joel Goldstein, Charlton Copeland, Peter J. Smith, Doug Williams, and Alan Howard for their insightful comments and suggestions on earlier drafts of this article. This Article was supported by a summer research grant from Saint Louis University School of Law. 


\section{INTRODUCTION}

Suppose that the federal government decides to pass new health and safety standards for the processing of meat. May it enforce these newly created federal rights by requiring states to send their inspectors to processing facilities periodically to monitor compliance? It may not. States of course may not enact regulations that contradict the federal standards, ${ }^{1}$ and depending on the scope of the regulatory scheme and the intent of Congress they may not be able to enact regulations at all. ${ }^{2}$ Moreover, a state may voluntarily agree to send inspectors in exchange for federal funds. ${ }^{3}$ But a state may not be subject to a unilateral command to fulfill federal objectives. ${ }^{4}$

Now suppose that the federal government also decides to enforce these new safety standards by creating a private cause of action available to individuals who consume tainted meat. May it enforce these newly created federal rights by requiring states to hear and enforce claims brought under the law? Now the answer is almost certainly that it may. With limited exceptions, the creation of a federal cause of action that may be brought by a plaintiff in a federal court simultaneously creates a right for the plaintiff to choose to bring that cause of action in state court instead. ${ }^{5}$ Of course, a plaintiff may decline to proceed in state court, and the power of removal means that the defendant may

${ }_{1}^{1}$ Florida Lime \& Avocado Growers, Inc. v. Paul, 373 U. S. 132, 142-143 (1963); Hines v. Davidowitz, 312 U.S. 52, 67 (1941).

2 Gade v. Nat'l Solid Wastes Mgmt. Assn., 505 U.S. 88, 115 (1992); Rice v. Santa Fe Elevator Corp., 331 U.S. 218, 230 (1947).

${ }^{3}$ Roderick M. Hills, Jr., The Political Economy of Cooperative Federalism: Why State Autonomy Makes Sense and "Dual Sovereignty" Doesn't, 96 MICH. L. REV. 813, 858 (1998).

${ }^{4}$ See, e.g., N.Y. v. United States, 505 U.S. 144, 168-69 (1992).

5 Indeed, the federal government need not even create this obligation explicitly. See Tafflin v. Levitt, 493 U.S. 455, 458-58 (1990) (discussing the presumption of concurrent jurisdiction between federal and state courts for claims arising under federal statutes). There are some limited exceptions to the concurrency presumption. These include express Congressional directive or by "unmistakable implication" found in the legislative history that create exclusive federal jurisdiction. Id. at 460-62. A court may also find "clear incompatibility" between state-court jurisdiction and federal interests. Id. at 464. Finally, the "valid excuse" doctrine, discussed further below, provides a tiny escape hatch for state courts to avoid hearing federal claims of their own volition. See infra note 10 and accompany text. 
decline even where the plaintiff does not. ${ }^{6}$ But the state itself will usually have no power to decline, and instead must expend its resources to fulfill federal objectives.

Why is this so? Why is it acceptable for the federal government to commandeer state judges but not state inspectors? The traditional answer has been that the scope of federal power with respect to jurisdiction is different and greater than other federal powers described in Article I. ${ }^{7}$ The Supreme Court has read the Supremacy Clause to extend to federal jurisdictional rules, meaning that a state may not create competing rules that would deny jurisdiction over a federal claim in cases where the federal rule would permit it. 8 Scholars uncomfortable with such a robust vision of federal supremacy have argued that the Court has reached the right conclusion for the wrong reason, and have suggested Article III or Article I as a substitute source for federal power to impose a jurisdictional obligation on the states. ${ }^{9}$ But the basic premise that state courts have an obligation to entertain federal claims has largely gone unquestioned.

Largely, but not entirely. One of us has argued elsewhere that this obligation is overly rigid and undesirable as a matter of policy. ${ }^{10}$ And in Haywood $v$. Drown, Justice Clarence Thomas penned a dissent that questioned its consistency with the original

${ }^{6} 28$ U.S.C. $§ 1441$ (2006).

7 Saikrishna Bangalore Prakash, Field Office Federalism, 79 VA. L. REV. 1957, 2012-13 (1993) (combining the Supremacy Clause with the State Judges Clause to support such power); Martin H. Redish \& Steven G. Sklaver, Federal Power to Commandeer State Courts: Implications for the Theory of Judicial Federalism, 32 IND. L. REV. 71, 89-91 (1998) (situating this power in the State Judges Clause combined with the Necessary and Proper Clause). The Court has concurred in this understanding, particularly in Printz, where Justice Scalia noted, "[t]he Constitution was originally understood to permit imposition of an obligation on state judges to enforce federal prescriptions, insofar as those prescriptions related to matters appropriate for the judicial power." Printz v. United States, 521 U.S. 898, 908 (1997) (emphasis in original).

${ }^{8}$ Haywood v. Drown, 129 S. Ct. 2108, 2114 (2009).

9 See, e.g., Brian T. Fitzpatrick, The Constitutionality of Federal Jurisdiction-Stripping Legislation and the History of State Judicial Selection and Tenure, 98 VA. L. REV. 839, 848 (2012); James Pfander, Federal Supremacy, State Court Inferiority, and the Constitutionality of JurisdictionStripping Legislation, 101 NW. U. L. REV. 191, 212 (2007).

10 Samuel P. Jordan, Reverse Abstention, 92 B.U. L. REV. _- (forthcoming 2012). 
meaning of the Constitution. ${ }^{11}$ Taking a cue from Haywood, this Article takes a close look at the original understanding of state court jurisdictional obligations. Part I begins by setting out the existing precedent that imposes substantial obligations on state courts to hear federal claims, subject to a very narrow exception. Part II considers the various sources of federal power that might support that precedent - the Supremacy Clause, Article III and Article I. While we certainly do not agree with all of Justice Thomas's assertions, our basic conclusion is that he was more right than wrong. Understood in its proper context, the original design of the constitution was not intended to infringe on the power of states to define the jurisdiction of their courts. Finally, in Part III we use the narrow question of state court jurisdictional obligation to press the broader point that considerations of intent and of shared expectations should play a role in any meaningful originalist methodology.

\section{FRAMING THE ISSUE}

States are often willing - and perhaps even eager-to open their courts to federal business. Indeed, a federal claim being decided in a state court is unremarkable. That said, the Constitution imposes requirements for how a federal claim must be treated once a state court chooses to exert jurisdiction. First and foremost, the state court must decide the claim according to federal law, and may not substitute some other law in its place. This applies clearly to the substantive rules of decision surrounding the federal claim, and in certain circumstances it may apply equally to the procedural rules attendant to the claim. ${ }^{12}$ A decision by a state court to hear a federal claim but to ignore these obligations is a straightforward violation of the Supremacy Clause. ${ }^{13}$

But what if a state decides that it does not want to hear the federal claim at all? Based primarily on pragmatic considerations, one of us recently argued that a state should have the authority to turn away federal business, at least when it does

${ }^{11}$ Haywood v. Drown, 129 S.Ct. 2108, 2118 (2009) (Thomas, J., dissenting).

${ }^{12}$ For a discussion of the precise contours of those circumstances, see Kevin M. Clermont, Reverse-Erie, 82 NotRE DAME L. REV. 1, $26-27$ (2006).

13 U.S. CONST. Art. VI cl. 2. 
so in a way that does not prejudice federally created rights. ${ }^{14}$ That suggestion is a departure from established cases, which have consistently held that a state's power to control its jurisdiction with respect to federal claims is constrained not by the principle of prejudice, but by those of discrimination and interference.

Testa $v$. Katt provides an early and instructive example of these principles. ${ }^{15}$ At issue in Testa was a claim brought in a Rhode Island state court against a seller who sold an automobile at a price exceeding the ceiling set by the federal Emergency Price Control Act. ${ }^{16}$ Under the terms of the act, the plaintiff was entitled to receive treble damages, and the state district court awarded just that. ${ }^{17}$ On appeal, the Rhode Island Superior Court struck the treble damages and instead entered a judgment using the state measure of damages, which was limited to the overcharge plus costs. ${ }^{18}$ On appeal yet again, the Rhode Island Supreme Court declined to award damages at all, and instead concluded that a federal action for treble damages could not be sustained in the state courts. ${ }^{19}$ The first two of these dispositions are constitutionally straightforward. The district court heard the federal claim and applied federal law to measure damages, a result that is unproblematic. The superior court, on the other hand, heard the federal claim but then applied state law to measure damages. That result disregards the supremacy of federal law, and is unacceptable.

The Rhode Island Supreme Court's treatment of the case is not nearly so straightforward. The court obviously did not award the treble damages called for by the federal law, but neither did it award damages measured by state law. Rather, its disposition was in the nature of a jurisdictional dismissal, and presumably left the plaintiff free to pursue his federal remedy elsewhere. That was not enough for Justice Black, who-speaking for a unanimous Court-concluded that Rhode Island's unwillingness to enforce the federal law "disregards the purpose and effect of

\footnotetext{
14 See generally Jordan, supra note 10.

15330 U.S. 386 (1947).

${ }^{16} I d$. at $387-88$.

17 Id. at 388.

$18 \mathrm{Id}$.

${ }^{19} \mathrm{Id}$.
} 
the [Supremacy Clause]." 20 At least since Testa, then, the Supremacy Clause has been interpreted to require not just that states treat federal claims in a certain way, but also that they hear federal claims in the first place. Or put differently, the Constitution affects a state's power to define its own jurisdiction.

That said, Testa did not hold that a state court is always compelled to hear federal claims presented to it. Instead, the Supreme Court has consistently declared that a state may refuse federal business if it has a valid excuse for doing so. ${ }^{21}$ Precisely what constitutes a valid excuse has been the subject of some dispute. The baseline requirement has consistently been that the state must apply a "neutral rule of judicial administration." 22 Neutral in this context means that the rule does not turn on the federal nature of the claim being presented. It is on this basis that the rule at issue in Testa failed. The Rhode Island Supreme Court would have permitted the state court to entertain a state cause of action for overcharging (with damages measured by state law), but would not entertain a parallel action rooted in federal law. By contrast, consider a rule that says that a state district court may only hear claims arising from actions that occurred within the territorial borders of the district. That rule provides a valid excuse for refusing a federal claim because it would apply equally to a state claim. ${ }^{23}$

So what then of a rule that suits against corrections officers may not be maintained in the state courts? Applying the notion of neutrality just developed, such a rule would appear to be acceptable because it is triggered by the identity of a party rather than the source of law, and would therefore apply equally to federal and state claims. In Haywood v. Drown, however, the Supreme Court struck the rule down even so. ${ }^{24}$ To explain that result, Justice Stevens concluded that the neutrality emphasized in earlier cases was a necessary but not sufficient condition for compliance with the Supremacy Clause. ${ }^{25}$ The problem he then

20 Testa, 330 U.S. at 389.

${ }^{21}$ Haywood v. Drown, 129 S. Ct. 2108, 2114 (2009).

$22 I d$.

23 See Douglas v. New York, N.H. \& R.H. Co., 279 U.S. 377, 387 (1912); Herb v. Pitcairn, 324 U.S. 117, 123 (1945); Missouri ex rel. Southern Ry. Co. v. Mayfield, 340 U.S. 1, 4-5 (1950).

${ }^{24}$ Haywood, 129 S. Ct. at 2115.

${ }^{25} \mathrm{Id}$. at 2116. 
identified with New York's rule was that it was jurisdictional in effect but not intent. As for intent, Stevens concluded that New York was motivated by hostility to the concept of official liability (at least in the prison context). ${ }^{26}$ But of course official liability is precisely the policy embedded in federal statutes, most notably in $\S 1983$, and therefore the New York rule really constituted a substantive disagreement with a federal law. Viewed this way, the rule is constitutionally problematic because a state is not entitled to disagree with federal law. And that is true even if the form of the disagreement is the introduction of a jurisdictional rule that preserves federal rights but forces them to be vindicated somewhere other than the state's courts. After Haywood, then, the Constitution acts as a significant constraint on the power of states to define the jurisdiction of their own courts. States may not create jurisdictional rules that apply exclusively to federal claims, and they also may not create jurisdictional rules that apply to both federal and state claims if the rule is motivated by a disagreement with federal law.

Writing for himself, Justice Thomas argued in dissent in Haywood that the entire line of cases just discussed is inconsistent with the original meaning of the Constitution. ${ }^{27}$ In its place, he presented a competing vision of state power of jurisdiction that is robust and not subject to federal control. This competing vision stems from a very basic premise: the Supremacy Clause has nothing to do with and nothing to say about jurisdiction. ${ }^{28}$ Instead, it merely defines the priority to be given to competing substantive laws once a court (whether federal or state) exerts jurisdiction in an action. ${ }^{29}$ Moreover, although Congress may have authority to remove cases that fall within the federal judicial power described in Article III from the state courts, nothing in that article supplies the converse power to compel states to take jurisdiction over federal cases. Therefore, so long as the state invokes a jurisdictional rule to close its courthouse doors to a federal claim, the constitution is not

${ }^{26} I d$. at 2115.

27 See id. at 2118-26 (Thomas, J., dissenting). Three other justices joined the final part of his dissent in which he accepted the precedent set by these cases but disputed their application in the instant proceeding. See id. at 2133.

28 Id. at 2126.

${ }^{29}$ Haywood, 129 S. Ct. at 2126 (Thomas, J., dissenting). 
offended, regardless of the rule's neutrality or intent. ${ }^{30}$

This reading of state jurisdictional control stands in stark contrast to the prevailing view. That may explain why the three justices who signed other parts of the dissent declined to join in Thomas's attempt at an originalist revision of established precedent. ${ }^{31}$ But a broader power to define and control state court jurisdiction might be desirable for other reasons, and may ultimately enhance rather than undermine federal-state relations. ${ }^{32}$ To the extent that the resistance to embrace such a broader power is rooted in a concern about its constitutionality, Thomas's revisionism is worth a close examination. It is to that examination that the next Part turns.

\section{ORIGINAL UNDERSTANDINGS}

The Court and many scholars ground state-court jurisdictional compulsion in the constitutional text. ${ }^{33}$ Originalist assessments of the plain language of the enacted text, they argue, support the notion that state courts are obligated to hear federal

${ }^{30}$ In his dissent, Thomas explains at length the precedent supporting the anti-discrimination principle. See $i d$. at 2126-31. There, he discusses why Testa was a proper decision-the Rhode Island court's refusal to hear the federal claim wasn't founded on a jurisdictional "rule" that was being invoked, but a sua sponte decision based on disagreement with federal law. Id. at 2129.

31 Justice Thomas's jurisprudence highlights the significant theoretical tension between originalism and stare decisis. See, e.g., Morse v. Frederick, 551 U.S. 393, 410-11 (2007) (calling for the abrogation of Tinker as inconsistent with Framer expectations); Kelo v. City of New London, 545 U.S. 469, 523 (2005) ("When faced with a clash of constitutional principle and a line of unreasoned cases wholly divorced from the text, history, and structure of our founding document, we should not hesitate to resolve the tension in favor of the Constitution's original meaning.). Other originalists share his views, though his dissents are probably the most tenacious statements of the position. See, e.g., Randy E. Barnett, Trumping Precedent with Original Meaning: Not as Radical as It Sounds, 22 Const. Comment. 257, 269 (2005) ("Where a determinate original meaning can be ascertained and is inconsistent with previous judicial decisions, these precedents should be reversed and the original meaning adopted in their place.”).

32 See Jordan, supra note 3 , at 55.

33 See, e.g., Haywood v. Drown, 129 S. Ct. 2108, 2114 (2009); Brian T. Fitzpatrick, The Constitutionality of Federal Jurisdiction-Stripping Legislation and the History of State Judicial Selection and Tenure, 98 VA. L. REV. 839, 848 (2012). 
claims absent a valid excuse. In Haywood, Stevens based this compulsion in the "anti-discrimination" principle of the Supremacy Clause. ${ }^{34}$ This understanding of the Clause includes supremacy commands not only for the substantive law applied in a case, but also in the jurisdictional laws which determine whether a state court must hear a case at all.

Our conclusion, detailed below, is that the Supremacy Clause contains no such jurisdictional component. We echo and expand on this point that Thomas made in his Haywood dissent. If this argument is true, then state-court jurisdictional compulsion cannot be situated in the Supremacy Clause alone. Instead, this power must flow from the natural operation of the Clause, i.e., the supremacy of a law enacted pursuant to a validly exercised Congressional power. The obvious next question is: Where else in the Constitution could a federal power to compel state court jurisdiction come from? The potential answers are Article III and Article I. After deconstructing the Haywood Court's Supremacy Clause anti-discrimination principle as a matter of original understanding, we will turn to these other clauses and show that, again as a matter of original understanding, neither can support state-court jurisdictional compulsion.

\section{A. Article VI and Federal Supremacy}

The Supremacy Clause embodies a counter-textual compromise. Akin to the Madisonian Compromise, discussed more fully below, the Framers and ratifiers crafted a "clear" text for the Clause that embodied a compromise far more nuanced. The Supremacy Clause's text is "clear" in that it does not distinguish between the kinds of laws states must recognize as supreme and binding. ${ }^{35}$ The reality of constitution-making requires us to dig deeper than the supposedly clear surface and into the murkier waters below. It is those depths that the real outlines of federal supremacy lay. In the end, the Supremacy Clause commanded obedience to substantive laws, but the debates and writings, coupled with a consideration of rejected alternatives, suggests that jurisdictional laws are not within its

\footnotetext{
34 Haywood, 129 S. Ct. at 2114-15.

$35 \mathrm{Id}$. at 2117.
} 
ambit.

Thomas's Haywood dissent devotes significant space to this argument. After attempting to establish state authority to control the subject-matter jurisdiction of their own courts in the face of federal claims, Thomas attacks the majority's contention that there is an "anti-discrimination" principle inherent in the Supremacy Clause, arguing that the Clause's power reaches only substantive, not jurisdictional, state laws. ${ }^{36}$ He sums this point up nicely when he states, "[T]he Supremacy Clause does not address whether a state court must entertain a federal cause of action; it provides only a rule of decision that the state court must follow if it adjudicates the claim."37 Thus the Supremacy Clause confers no jurisdiction of its own accord but is merely a choice-oflaw rule. In this view of the Supremacy clause, federal laws that purport to control the jurisdiction of state courts are unconstitutional and therefore not entitled to Supremacy. Thomas relies on the debates in the Philadelphia Convention to show that the Framers rejected the notion that the Supremacy Clause compels state courts to hear federal claims. ${ }^{38}$

\section{The Convention}

Context is critical in assessing the underdetermined language of the Supremacy Clause. The Convention debates and other Founding-era writings provide helpful illumination. In the Convention, the New Jersey Plan was a rejected alternative to the Virginia Plan (and ultimately the Madisonian Compromise). The New Jersey Plan required state-court adjudication of federal claims "in the first instance." 39 The other major alternative was Madison's proposed the Congressional negative on any state law, discussed in the Article III context below, which was struck down

${ }^{36} I d$. at 2123 (Thomas, J., dissenting).

${ }^{37}$ Haywood, 129 S. Ct. at 2123.

38 See id. at 2123-25.

39 Id. at 2123; see 1 FARRAND's RECORDS, supra note 47 , at 242-45. The precise language from the third volume of Farrand is that it was Luther Martin's "wish and hope" that state courts, and not lower federal courts, would hear federal claims. $3 \mathrm{id}$. at 287 . This is not immediately denotative of compulsion, but the language of the proposed plan is sufficient to show that such "wish and hope" would have been carried into action if it had been adopted. 
as violative of state autonomy and sovereignty. ${ }^{40}$

The Supremacy Clause was drawn out from the defeated New Jersey Plan and adopted in the final Constitution, but the portion of the Plan compelling state-court jurisdiction was not. 41 Two arguments can flow from this result. First, the jurisdictional compulsion provision was rejected and the Supremacy Clause does not intend such a compulsion. ${ }^{42}$ Alternatively, the Framers felt that the two measures were duplicative and chose to adopt the Supremacy Clause because it could serve to compel statecourt submission to both jurisdictional and substantive laws standing alone. While the former argument is undoubtedly stronger, honest reliance on Framer intent requires us to be openminded about the universe of possible outcomes. Thus we acknowledge that the rejection of the New Jersey Plan's jurisdictional mandate can cut either way: either it can show that the final version abandoned that requirement, or that the Supremacy Clause was intended to contain that requirement on its own terms.

Nevertheless, Thomas argues strongly in Haywood that such context trumps the otherwise clear language of the Clause. First, he points out that the Supremacy Clause was revived from the New Jersey Plan and incorporated into the Constitution in the context of addressing which federal branch, the courts or Congress, would best vindicate the superiority of federal law. ${ }^{43}$ This argument has some merit in light of the discussion of Article III and state jurisdictional freedom below. It is possible that Article III "end[ed] the fight over state-court jurisdiction," 44 giving state courts freedom to refuse jurisdiction of federal claims.

40 Haywood, 129 S. Ct. at 2124 (Thomas, J., dissenting); see also Letter from James Madison to Thomas Jefferson (Oct. 24, 1787), in 10 THE PAPERS OF JAMES MADISON, supra note 72, at 207-15 (outlining and advocating his failed plan for a Congressional power to negative any state laws).

41 James S. Liebman \& William F. Ryan, "Some Effectual Power": The Quantity and Quality of Decisionmaking Required of Article III Courts, 98 ColuM. L. REV. 696, 725, 730 (1998) (reporting that the New Jersey Plan explicitly assigned original jurisdiction of federal matters to state courts, and that Luther Martin's language for a Supremacy Clause was salvaged from the otherwise defeated Plan).

42 See Solum, supra note 42 , at 34 (originalism allows negative implications to inform interpretation where positive text is ambiguous or vague).

${ }^{43} I d$.

${ }^{44}$ Haywood, 129 S. Ct. at 2124 (Thomas, J., dissenting). 
With that understanding in mind, jurisdictional disputes were resolved not in the Supremacy Clause but in Article III. From this would follow the assumption that the Supremacy Clause did not address jurisdiction. This rightly applies the "surplusage" lesson from Marbury. ${ }^{45}$

Thomas next argues that since (a) Madison's proposed Congressional negative was directed to substantive laws and (b) the Supremacy Clause was an alternative to that proposal, the Supremacy Clause must be limited to the supremacy of substantive federal laws, not procedural or jurisdictional ones. ${ }^{46}$ In the spirit of fair analysis, this argument must be laid out as less persuasive.

Thomas provides no support for his first premise that Madison's negative would not reach jurisdictional laws except for the footnote comment that Madison thought little of state court competency over federal matters. ${ }^{47}$ He brashly claims that "there can be no question" that Madison's proposal was concerned solely with substantive laws and not state-court jurisdiction. ${ }^{48}$ But, what is it about jurisdictional laws that place them outside the "laws" of the states as mentioned in Madison's proposal? 49 Even if Madison thought ill of state court judges, that is not enough to show that he would sacrifice federal supremacy in order to avoid conflict with their parochialism. On the contrary, Madison's letter to Jefferson, cited by Justice Thomas, is ardent in its

45 See supra note 105 and accompanying text.

${ }^{46}$ Haywood, 129 S. Ct. at 2124-25 (Thomas, J., dissenting).

${ }^{47} \mathrm{Id}$. at 2124.

48 Id. at 2125 .

49 Scholars have devoted countless pages to the differences between procedural and substantive laws. See, e.g., Walter Wheeler Cook, "Substance" and "Procedure" in the Conflict of Laws, 42 YALE L. J. 333 (1933); Edgar H. Ailes, Substance and Procedure in the Conflict of Laws, 39 MicH. L. REV. 392 (1941); D. Michael Risinger, Substance and Procedure Revisited With Some Afterthoughts on the Constitutional Problems of "Irrebuttable Presumptions," 30 UCLA L. REV. 189 (1982). More recent work has sought to elucidate the more nuanced distinctions between procedural and jurisdictional laws. See, e.g., Scott Dodson, In Search of Removal Jurisdiction, 102 Nw. U. L. REV. 55 (2008); Howard M. Wasserman, Jurisdiction, Merits, and Procedure: Thoughts on a Trichotomy, 102 Nw. U. L. REV. 1547 (2008); Scott Dodson, Mandatory Rules, 61 STAN. L. REv. 1 (2008). Though the different types of laws serve different functions, nowhere do any of these authors intimate that jurisdictional laws are simply not laws. 
support for the federal government and the vital necessity of federal supremacy. ${ }^{50}$ It is far more in line with the plain language of the proposal to interpret "laws" as granting Congress full power over any state law, substantive, procedural, or jurisdictional. Thomas claims that the negative "merely provided that state laws could be directly nullified if Congress found them to be inconsistent with the Constitution or laws of the United States." 51 This misses the critical question entirely: are state jurisdictional laws like the one at issue in Haywood inconsistent with the Supremacy Clause's mandate? The ratification debates and other Founding-era writings hint at the answer that state sovereignty was too important to incorporate jurisdictional compulsion.

\section{The Ratification Debates}

Nearly every ratification convention expressed similar concerns over the broad language of the Supremacy Clause. Some conventioneers conveyed this sentiment in vague terms as a threat to their "Rights and Privileges."52 More sensational advocates claimed that such a provision would "destroy all the laws of the states" 53 and "produce an abolition of the state governments." 54 The Clause, in their view, would create a federal government prone to become "despotic." 55

The most influential of these attacks on the Clause was a circular letter issued by the Albany Anti-Federalist Committee. ${ }^{56}$ The letter contained numerous objections to the Constitution as proposed, but for our purposes, one of its strongest objections was that the laws of the national government

50 See Letter from James Madison to Thomas Jefferson (Oct. 24, 1787), in 5 The Writings OF JAMES MADISON 23-32 (Gaillard Hunt ed., 1904) (enumerating reasons why federal supremacy was critical, including managing factioning among the states, protecting individuals by allowing control over state-created injustices, and the general inadequacy of morality or religion to restrain the oppressive tendencies of the majority will).

${ }^{51}$ Haywood, 129 S. Ct. at 2125 (Thomas, J., dissenting).

52 MAIER, supra note 109, at 149.

${ }^{53} \mathrm{Id}$. at 191 .

${ }^{54} \mathrm{Id}$. at 419 .

$55 I d$. at 152.

${ }^{56} \mathrm{Id}$. at 333 . 
are to be the supreme law of the land, and the judges in every state are to be bound thereby, notwithstanding the constitution or laws, of any state to the contrary - A sweeping clause, which subjects every thing to the controul of the new government. 57

This letter went so far as to call for wholesale rejection of the Constitution, because compromise with the later hope of concession was a foolish and unachievable ideal. ${ }^{58}$

Of course, compromise was in fact reached, and the viable concerns over state sovereignty were thereby assuaged (if only in part). The Federalist response encapsulates the counter-textual understanding of the Clause that answered the Albany circular's objection:

The words "made in pursuance of the Constitution," which are fully expressed in the form of government submitted to us, are willfully omitted by the objectors to deceive the people into a belief that the New System of Government will have power to make laws in all cases whatsoever[.] ${ }^{59}$

The Antifederalists' calls for a "limited and defined" federal supremacy 60 were thus not answered in-text, but in mutual understanding.

This excerpt in particular refutes the Haywood Court's inclusion of an anti-discrimination principle in the Supremacy Clause, because it underscores the vital textual limitation that only acts made "in pursuance of the Constitution" are to be given supremacy. Thus, the Court cannot locate any element of statecourt jurisdictional compulsion in the Clause itself; they must instead site it in another validly exercised Congressional power. The Clause has no force of its own, but only gives supreme effect

57 Address of the Albany Antifederal Committee, April 10, 1788.

58 MAIER, supra note 109, at 333-34.

59 The 35 Anti-Federal Objections Refuted, by the Federal Committee of the City of Albany, April 1788.

${ }^{60}$ MAIER, supra note 109, at 420. 
to other powers granted to Congress and validly exercised. Bradford Clark has made similar a point from a textual and structural perspective. ${ }^{61}$

\section{Early Congress}

The records of early Congressional debates bolster this interpretation of the Supremacy Clause in light of the implications of the Madisonian negative. There, Congressmen fiercely debated the need for lower federal courts. While we will show that the Framers and ratifiers did not imbue them with the authority to continue this debate, their records nevertheless show that they concluded that they were bound to create lower federal courts.

Representative Fisher Ames explained during the debate over the Judiciary Act of 1789 that "[t]he law of the United States is a rule to [state-court judges], but no authority for them. It controlled their decisions, but could not enlarge their powers." 62 Ame's comment concerning the dichotomy of "rules of decision" and "authority" is not fully clear without more context, however. When examined in context, Ames does not defend the ability of the state courts to refuse jurisdiction, but instead argues that state courts cannot hear claims under new federal statutes at all because "offenses against statutes of the United States, and actions, the cognizance whereof is created de novo, are exclusively of Federal jurisdiction."63 Despite not advocating for state-court jurisdictional freedom, Ames's argument reaches the same ends, albeit through a broad federal-court exclusive-jurisdiction regime.

Representative Sedgwick felt that state courts "might refuse or neglect to attend to the national business," and so lower federal courts were necessary to deal with this eventuality. ${ }^{64}$ Sedgwick's primary aim was to show "how dangerous it would be" to make the state governments "sole guardians of the national faith and honor." 65 Even though his comments did not reflect

61 Bradford R. Clark, The Supremacy Clause as a Constraint on Federal Power, 71 GEO. WASH. L. REV. 91, 103-04 (2003).

621 ANNALS OF CONG., supra note 63, at 808.

${ }^{63} \mathrm{Id}$.

${ }^{64} \mathrm{Id}$. at 806.

${ }^{65} \mathrm{Id}$. 
support for state autonomy, they recanted the common refrain lower federal courts were necessary because state-court parochialism would undermine enforcement of federal policy. ${ }^{66}$ This goal evidences so much distrust of state courts that a jurisdictional obligation, which would give a greater share of federal business to state courts, would likely be far from the Framers' minds. Akin to Ames's argument described above, Sedgwick's conclusions support state-court jurisdictional freedom but come to that conclusion from a different angle, one concerned more with the danger of state-court undermining of federal supremacy.

William Patterson's notes on a speech on the Judiciary Act in the early Senate debates record that the Constitution requires only an oath of "Allegiance and not an Oath of Office," and therefore the federal government "[c]annot compel them to act-or to become our Officers." 67 Patterson's notes are not taken in prose form, nor transcribed into such form. Instead, they exist simply as a series of broken phrases which do not give a great deal of definite insight into Patterson's thoughts or the contents of the speech itself. While Patterson's conclusions are attractive to our theory, we must note that this context leaves little satisfaction as to interpretive certainty. One might be loath to resort to such piecemeal reflection as indicative of legislative intent. 68 To place it at a distance of over two hundred years does nothing to assuage the reader's unease.

Not all speakers supported either jurisdictional freedom or exclusive-jurisdiction regimes. Mr. Stone rested compelled statecourt jurisdiction on federalism concerns. He argued that even if federal courts may one day be necessary, state courts were currently sufficient as arbiters of federal law. ${ }^{69}$ He also noted that using state courts for federal claims "would be...one of the strongest chains by which the Union is bound; one of the strongest cements for making this Constitution firm and

66 See supra notes 87-90 and accompanying text.

67 Notes of William Patterson from Speech on Judiciary Act (June 23, 1789), in 9 DOCUMENTARY History OF THE FIRST FEDERAL CONGRESS, 17891791, at 477 (Kenneth R. Bowling \& Helen E. Veit eds., 1988).

68 This is precisely a case of "unavoidably vague" Framer language that leaves "substantial uncertainties" in its wake. Whittington, supra note 14, at 611-12.

${ }^{69} I d$. at $810-11$. 
compact."70

Mr. Harper argued that Congress "cannot enforce on the State courts, as a matter of duty, a performance of the acts we confide to them." 71 Harper asserted that there was "no cause to complain' 'until [state courts] refuse to exercise' the jurisdiction granted over federal claims."72 Here, Mr. Harper pointed out that, at the time of the debate, there was no necessity for federal courts. ${ }^{73}$ This is because the state courts were, at this time, accepting adjudication of federal rights. ${ }^{74}$ He saw no need to engage in such a demanding enterprise as creating lower federal courts until the state courts refused to exercise Congressionallygiven jurisdiction. ${ }^{75}$ Until such time, Congress had "no cause to complain."76

This does not undermine state-court autonomy and each state's ability to amend the subject-matter jurisdiction of its own courts. Some later speakers in the same debate forcefully argue in favor of lower federal courts, noting that the plain meaning of Article III did not leave the creation of lower federal courts to expediency but rather mandated their creation. ${ }^{77}$ Thus, even if the judicial balance at the time of ratification was not tested by the existence of lower federal courts, when and if it was, state courts should maintain jurisdictional freedom.

Furthermore, the political context as a whole shows that federal supremacy did not demand jurisdictional supremacy. In light of the Articles of Confederation, the very failure of which was the major motivation for the Constitutional Convention, ${ }^{78}$ the Framers were especially concerned with ensuring an effective national government. A more assertive federal presence was required to guide the Union in matters beyond the jurisdiction of

${ }^{70} \mathrm{Id}$. at 811.

${ }^{71}$ Haywood, 129 S. Ct. at 2125 (Thomas, J., dissenting) (quoting 10 ANNALS OF CoNG., supra note 122, at 892).

72 Id.

7310 ANNALS OF CONG., supra note 122, at 892.

${ }^{74} \mathrm{Id}$.

${ }^{75} \mathrm{Id}$.

${ }^{76} \mathrm{Id}$.

77 Id. at 893.

78 John C. Yoo, The Judicial Safeguards of Federalism, 70 S. CAL. L. REV. 1311, 1365 (1997). 
any one state. ${ }^{79}$ Thus the Supremacy Clause ensured that the new federal scheme under the Constitution empowered the national government to make, enforce, and interpret its own body of laws. This did not include a duty for state courts to adjudicate federal claims, but merely an oath to not contravene such laws when properly brought before them. ${ }^{80}$ Madison argued this point eloquently, pointing out that state courts, unlike the federal courts, were bound to uphold the laws of the other sovereign. ${ }^{81}$ Contrary to the majority's reasoning in Haywood, Framers feared a "clashing of jurisdiction" would result in too much power being confided in the states. ${ }^{82}$ To do oblige untrustworthy states to adjudicate federal matters would undermine federal authority to pronounce and effectively enforce national policy.

\section{The State Judges Clause}

The fact that Article VI contains language specifically directed at state judges does not undermine the conclusion reached above. ${ }^{83}$ Rather, the clause merely reinforces the idea

79 Indeed, while some worked to ensure that the federal judiciary would not intrude into matters of local, state-level concern, M.E. BRADFORD, FOUNDING FATHERS: BRIEF LIVES OF THE FRAMERS OF THE UNITED STATES CONSTITUTION 180-81, 191 (2d ed. 1994), this concern is inapposite to the question of state adjudication of federal law. In that area, one is not concerned with federal overreaching but instead with a lack of necessary participation from the states.

80 See The Federalist No. 27 (Alexander Hamilton) (Jacob E. Cooke ed., 1961) ("It merits particular attention in this place, that the laws of the confederacy, as to the enumerated and legitimate objects of its jurisdiction, will become the SUPREME LAW of the land; to the observance of which, all officers legislative, executive and judicial in each State, will be bound by the sanctity of an oath.") (emphasis in original).

81 The Federalist No. 44, at 307 (James Madison) (Jacob E. Cooke ed., 1961).

821 AnNals of Cong., supra note 63, at 829. Mr. Gerry noted that Congress is empowered "to suppress any system injurious to the administration of this constitution" through its necessary and proper powers. Id.; see also Essay of A Democratic Federalist, in 3 THE CoMPLETE ANTIFEDERALIST, supra note 91, at 59 (conceding that "in case of a conflict of jurisdiction between the courts of the United States, and those of the several Commonwealths, is it not easy to foresee which of the two will obtain the advantage").

83 U.S. Const. art. VI, cl. 2 (“... and the judges in every state shall be bound thereby, anything in the Constitution or laws of any State to the contrary notwithstanding.") 
that state judges were bound to respect duly enacted federal laws, and did not reach the question of whether they were obligated to adjudicate federal matters in the first instance. The debates at the Federal Convention evidence this intent, particularly $\mathrm{Mr}$. Randolph's assertion that, in order to prevent competition between the national and state laws in state courts and "[t]o preserve a due impartiality" respecting those laws, "they ought to be equally bound to the Natl. Govt. The Natl. authority needs every support we can give it."84 Joseph Story echoed Madison's reasoning when he pointed out:

The judges of the state courts will frequently be called upon to decide upon the constitution, and laws, and treaties of the United States; and upon rights and claims growing out of them. Decisions ought to be, as far as possible, uniform; and uniformity of obligation will greatly tend to such a result. 85

Story's concern with uniformity of decision underscores the Clause's substantive focus. The obligation to enforce federal law by taking jurisdiction of cases arising under it is not equivalent to the obligation to uphold federal law in cases properly before a court. Decisions will not be more uniform because state courts must hear federal claims, but only because state courts must sustain federal law in federal claims adjudicated.

A significant body of other Founding-era writings expresses strong misgivings about the unduly broad power of the federal government. For example, many Framer voices cautioned that the Necessary and Proper Clause would lead to oppressive expansion of Congress's power. ${ }^{86}$ Likewise, they feared that the

841 FARRAND's RECORDS, supra note 47, at 203. Thomas attempted to counter the oath-obligation, as noted above. See supra note 128 and accompanying text. However, as was shown above, his primary source was so weak as to be wholly unreliable for a conscientious reader. See supra note 129-130 and accompanying text.

85 STORY, supra note $89, \S 1839$.

86 New York Ratifying Convention, in 2 ELLIOT's DEBATES ON THE FEDERAL CONSTITUTION 398 (Jonathon Elliot ed., 2nd ed. 1888); Virginia Ratifying Convention, in 3 THE PAPERs OF GEORGE MASON, 1725-1792, 1084-85 (Robert A Rutland ed., 1970); BRADFORD, supra note 145, at 186 (danger of "implied 
Supremacy Clause would effect a practical dissolution of the states as coequal sovereigns in the overall federal scheme. In fact, Mr. Gerry, while advocating for lower federal courts, expressed a view strikingly similar to the "valid excuse" doctrine at issue in Haywood: "[y]ou cannot make Federal courts of the State courts, because the constitution is an insuperable bar; besides, the laws and constitutions of some States expressly prohibit the State Judges from administering, or taking cognizance of foreign matters." 87 Likewise, St. George Tucker contended that the reach of federal jurisdiction would "wholly superced[e]" the states' judicial powers by compelling their aid in attending to that jurisdiction. ${ }^{88}$ These reactionary concerns were well-taken and were embodied in one of the most fundamental principles of constitutional interpretation: what is not enumerated in the Constitution as a federal power is excluded. ${ }^{89}$ This notion is strongly at odds with a desire to grant power to the federal government.

powers"); but see Alexander Contee Hanson, Remarks on the Proposed Plan of a Federal Government, in PAMPhlETs on the CONSTITUTION OF THE UNITED STATES 241-43 (Paul Leicester Ford ed., 1968) (discussing how the Necessary and Proper Clause will only expand Congress's powers by necessary implication). Despite Hanson's rebuttal, history has shown the expansive nature of the Necessary and Proper Clause. John Marshall himself supported this view of the Clause as the appropriate one in McCulloch. McCulloch v. Maryland, 17 U.S. 316, 354-55 (1819) (concluding that the reach of the Necessary and Proper Clause is not limited to cases of "indispensabl[e]" necessity, which is an interpretation that is "so gross an absurdity [that it] cannot be imputed to the framers of the constitution").

871 ANNALS OF CONG., supra note 63, at 828.

88 St. George Tucker, 1 BLACKSTONE'S COMMENTARIES 350-51 (1803). Writing on the implications of New York and Printz and their anticommandeering principle, Roderick Hills argued that the Founders feared that preemption, not commandeering, would emasculate state governments by depriving them of meaningful subject-matter jurisdiction. Roderick M. Hills, Jr., The Political Economy of Cooperative Federalism: Why State Autonomy Makes Sense and "Dual Sovereignty” Doesn't, 96 MicH. L. REV. 813, 833 (1998).

89 Marbury v. Madison, 5 U.S. (1 Cranch) 137, 174 (1803). The "default rule," proffered by Thomas himself in U.S. Term Limits $v$. Thornton, is similar to Marshall's principle in that it reserves all powers not enumerated in the Constitution to the states. 514 U.S. 779, 848-50 (1995) (Thomas, J., dissenting). He discussed in detail how this rule stands even in the face of the broad necessary-and-proper power conveyed in McCulloch. Id. at 853-55. 


\section{B. Article III and Constitutional Necessity}

In arriving at Article III's final formulation, the Framers primarily considered the Virginia and New Jersey Plans. ${ }^{90}$ They arrived at the Madisonian Compromise, which allowed, but did not require, Congress to create lower federal courts. ${ }^{91}$ Many scholars in the business of constitutional interpretation readily submit to the notion that Article III, section one's language that "[t]he judicial Power of the United States, shall be vested in one supreme Court, and in such inferior Courts as the Congress may from time to time ordain and establish" conclusively established the result of the Madisonian Compromise. ${ }^{92}$ The Madisonian Compromise has often been cited for this principle.

History, however, accommodates a very different reading, one that emphasizes the practicality of the Framers' compromise and the real force of their intentions. Michael Collins has also challenged this traditional view of the Compromise on a number of grounds. ${ }^{93}$ We argue here that, including his contribution of the prospect of enclaves of federal exclusivity, ${ }^{94}$ a wide review of original sources shows that the Compromise was more settled than a mere "may/shall" distinction implied. Many Framers viewed the "power" of Congress to create lower federal courts in Art. III as non-discretionary. ${ }^{95}$ Indeed, they viewed their grant of discretion as pertaining only to the "number and quality" of the lower federal courts, not to their very existence. ${ }^{96}$ Herbert Wechsler similarly argued in his foundational work on federalism that the Madisonian Compromise did not result in an understanding that federal courts were capable of not existing, but merely that their creation was more expediently left to the

901 The Records of the Federal Convention of 1787 20-22 (Max Farrand ed., 1937) [hereinafter FARRAND's RECORDS]; 1id. at 242-45.

${ }^{91}$ Haywood, 129 S. Ct. at 2120 (Thomas, J., dissenting).

${ }^{92}$ See supra note 1.

${ }^{93}$ See Collins, supra note 54, at 59-78 (arguing that since the Framers and other Founding-era writers recognized "enclaves" of exclusive federal jurisdiction, lower federal courts were accepted as necessity); but see Pfander, supra note 1, at 593 ("The Madisonian compromise left the decision whether to establish lower federal courts in the hands of Congress, thus leaving open the possibility there might be no inferior courts.").

94 See supra note 158.

95 Hamilton, supra note 71, at 488; infra Part III.A.2.

961 ANNALS OF CONG. 818 (1789) (Joseph Gales ed., 1834). 
first Congress. ${ }^{97}$ Though the language of the Constitution gave Congress discretion in the matter, there are powerful reasons to assume that this was merely a linguistic, and not practical, exercise. ${ }^{98}$

\section{The Convention}

In the Convention debates themselves, much controversy ensued from the proposed Virginia Plan, which created both a single supreme court and inferior federal tribunals. ${ }^{99}$ John Rutledge argued that lower federal courts would impermissibly encroach on state jurisdiction. 100 By giving state courts original jurisdiction over all federal claims in the first instance, Antifederalists could allay their fears of federal domination of the states. ${ }^{101}$ National uniformity, he argued, would be preserved by the Supreme Court's broad appellate jurisdiction. ${ }^{102}$

Nevertheless, Madison and others effectively argued that inferior federal tribunals were important in ensuring effectual national government. Without them, parties would suffer the oppression of "biassed [sic]" and "dependent" state judges and the "local prejudices" of a local jury. ${ }^{103}$ One cannot rely, as Rutledge would, on appeals from state courts to the Supreme Court. Considering the state of transportation technology in the late eighteenth century, Madison rightly noted that such appeals would carry litigants far away from their homes, at great expense. ${ }^{104}$ Furthermore, appeals from state courts would inundate and overwhelm a single Supreme Court. 105

Wilson offered in support of lower federal courts the prospect of cases involving foreigners and peculiarly federal

${ }^{97}$ See Herbert Wechsler, The Political Safeguards of Federalism: the Role of the States in the Composition and Selection of the National Government, 54 COLUM. L. REV. 543, 544, 548 (1954).

98 See supra notes 73-77 and accompanying text.

99 James S. Liebman \& William F. Ryan, "Some Effectual Power": The Quantity and Quality of Decisionmaking Required of Article III Courts, 98 COLUM. L. REV. 696, 715 (1998).

1001 FARRAND's RECORDS, supra note 154, at 124.

${ }^{101}$ Liebman \& Ryan, supra note 164, at 716.

${ }_{102} I d$.

1031 FARRAND’s RECORDS, supra note 154, at 124.

$104 I d$.

${ }^{105} I d$. at 716 . 
matters-namely, admiralty. $106 \mathrm{Mr}$. Sherman proceeded to argue that lower federal courts would incur great expense. ${ }^{107}$ In a sharp rebuttal, Mr. King pointed out that lower federal courts "would cost infinitely less than the appeals prevented by them." 108 Additionally, Nathaniel Ghorum advocated for lower federal courts on the ground that they would give Congress some meaningful efficacy. ${ }^{109}$ Ghorum went on to observe that federal admiralty courts were not only already in existence in some states, but that there were "no complaints...by the States." 110 The lack of objection from the states themselves seems to render the debate moot, at least in some respects. One need not argue that the federal courts impinge on state autonomy if such a system existed without producing the chaos that Rutledge or Luther Martin foretold.

This compromise is also important in the context of its alternative proposals. The primary alternative was Madison's brainchild, a Congressional negative applicable to any state law.111 Anti-Federalists sharply opposed this proposal as impermissibly broad federal encroachment on state autonomy. ${ }^{112}$ The compromise that resulted, then, was a sort of "lesser evil" in their eyes. Nevertheless, while Liebman and Ryan have argued that these debates produced a text that was "unusually authoritative" in its final form, they also admit that "[t]he Compromise...did not resolve the deep disagreement that prompted it."113 Neither side was totally satisfied with the result. And, even if the Compromise was authoritative of the result of these debates, we argue that the result itself contained clear connotations for Congressional action post-ratification.

The argument that lower federal courts were

${ }^{106}$ Id.; see also Michael G. Collins, Article III Cases, State Court Duties, and the Madisonian Compromise, 1995 WIS. L. REV. 39, 59-62 (1995) (arguing that many at the Convention believed certain "enclaves" of exclusive federal jurisdiction existed).

1071 FARRAND's RECORDS, supra note 47 , at 125.

$108 I d$.

109 Haywood v. Drown, 129 S. Ct. 2108, 2120 (2009) (Thomas, J., dissenting).

1102 FARRAND's RECORDS, supra note 47, at 46.

${ }^{111}$ Liebman \& Ryan, supra note 164, at 710.

112 Id. at 718 .

${ }^{113} I d$. at 707,718 . 
constitutionally required at the Founding has substantial relevance to our primary question of whether state-court jurisdictional compulsion is supported by originalist analysis. If lower federal courts were not constitutionally mandated, it is theoretically possible that Congress could have chosen not to create them at all. If this was the case, some courts would have to have been available to hear many federal claims in the first instance. The original jurisdiction of the Supreme Court did not extend to every case or controversy cognizable under Article III. Thus, state-court jurisdictional compulsion would comport with the original understanding that Congress could enlist state courts as an alternative to creating a lower federal court system.

This is the classic argument we attempt to refute. Instead of vesting Congress with discretion to create or not create lower federal courts, we argue that the "choice" embodied in Article III, Section I's language was illusory, a linguistic relic that did not properly reflect the compromise reached in the Framers' and ratifiers' minds. Lower federal courts were, in their minds, necessary to an effectual federal government. If lower federal courts were constitutionally required, then there can be no argument that Congress had the implicit to commandeer state courts out of necessity. With lower federal courts in place, there were sufficient fora in place to hear federal claims of all types. Accepting this view, state-court jurisdictional compulsion is not supported by Article III.

\section{The Ratification Debates}

Ratification debates were both diverse and predictable: predictable because many of the same arguments and counterarguments arose at each, but diverse in the nuanced concerns each set of debaters proposed and the uniquely powerful arguments some were able to muster. The debates in the ratification conventions over state- and federal-court jurisdiction and the creation of lower federal courts fit into this mold. Nevertheless, the conclusions that lower federal courts were required and that state jurisdiction should be preserved are strongly supported by these debates.

First, most state ratifying conventions were preeminently concerned with protecting state autonomy and sovereignty. State 
courts, they argued, should retain their pre-existing jurisdiction. 114 They already had plenty of business to keep them busy, 115 but overbroad federal jurisdiction might leave them with little left to do. ${ }^{116}$ In another bout of compromise that focused on post-ratification resolution, Congress enacted the Judiciary Act of 1789 and assuaged state fears by instituting the complete diversity and amount-in-controversy requirements for federal diversity jurisdiction. ${ }^{117}$

The focus on jurisdiction is important here. Whereas most debates focused on the extent of federal jurisdiction, few debated the need for federal courts themselves.118 Such courts were favored because, as echoed in other original sources, a strong national judiciary was necessary to remedy the defects of a statedominated confederation. ${ }^{119}$ These courts would also give teeth to a much-desired bill of rights, protecting individuals from state oppression. ${ }^{120}$ In this way, lower federal courts were vital to instituting the "double security" for individual rights that Hamilton envisioned. 121

Such courts would also save litigants the time and expense of travel to the Supreme Court for appeals. ${ }^{122}$ This point may be less relevant for today's litigants, but the compromise struck at the Founding accommodated the glacially slow travel technology of the time. Further, while some argued that federal courts would eviscerate state court power, ${ }^{123}$ others acknowledged that instituting state courts as federal courts would serve the very same oppressive function. By constituting state courts as federal tribunals, the state courts would forgo their state loyalties and uphold federal power at the expense of state sovereignty. ${ }^{124}$

A final and vital piece of this compromise was trust.

114 MAIER, supra note 109, at 290.

$115 \mathrm{Id}$.

116 Id. at 417.

${ }^{117} \mathrm{Id}$. at $464-65$.

118 Compare id. at 151-52, 197, 200, with id. at 190, 339, 308.

${ }^{119} \mathrm{Id}$. at $18,287$.

$120 \mathrm{Id}$. at 445 .

${ }^{121} I d$. at 449 .

122 Id. at 418 .

${ }^{123} I d$. at 65-66, 83 (but noting that the document gained little circulation), 87, 235, 262, 281.

${ }^{124} \mathrm{Id}$. at 287-89. 
Ratifiers needed to trust the first Congresses to "do their duty" and create lower federal courts. ${ }^{125}$ Just as the conventions proposed amendments for Congress's post-ratification consideration, here they relied on Congress to create lower federal courts despite their textual authority not to.

\section{Other Founding Sources}

Other arguments proposed in various Founding-era writings and early Congressional debates echo the sentiments of the Framers and ratifiers that lower federal courts were required in all but name. One such argument is that the independence of the federal judiciary was essential to its proper function as a check on Congress and the President. ${ }^{126}$ A separate and distinct judicial branch, divorced from "jarring interests" and dependence on political constituency, was needed to render the federal plan stable. ${ }^{127}$ The state judiciaries were subject to the tides of public opinion and thus lacked the requisite independence. ${ }^{128}$ Since the state judges were burdened with political allegiance, they could not be used as effective arbiters of federal law. ${ }^{129}$ Their dependence on political support undermined the neutral,

$125 \mathrm{Id}$. at 289, 446.

126 Alexander Hamilton, Remarks in the New York Ratifying Convention (June 27, 1788), in SELECTED WRITINGS AND SPEECHES OF ALEXANDER HAMilton at 229 (Morton J. Frisch ed., 1985); ThE Federalist No. 78 (Alexander Hamilton). Despite the need for judicial independence, some Framers expressed concern over the underestimated power the federal judiciary might wield. Letter from Thomas Jefferson to Thomas Ritchie (Dec. 25, 1820), in ThOMAS JeFFERSON ON CONSTITUTIONAL Issues: SELECTED Writings, 1787-1825, at 31-32 (1962); William RAWLE, A VieW OF THE CONSTITUTION OF THE UNITED STATES OF AMERICA 199-200 (2nd ed. 1829).

127 John Adams, Thoughts on Government, in The Political Writings of JoHn ADAMs at 90 (George A. Peek, Jr. ed., 1954). The editor, Professor George Peek, notes in his introduction to the essay that "Adams' views well represented the climate of opinion" at the time, which is exactly the sort of consensus view which Thomas should, as an originalist, have sought. George A. Peek, Introduction to John Adams, Thoughts on Government, in THE POLITICAL WRITINGS OF JOHN ADAMS, supra, at 84.

128 Some went so far as to claim not only political allegiance, but also personal corruption or prejudice, was a strong reason not to trust state judges. 1 ANNALS OF CONG., supra note 63, at 822.

129 Joseph Story, 3 COMMENTARIES ON THE CONSTITUTION OF THE UNITED STATES $§ 1583$ (1833). 
principled manner of adjudication that was vital to the balanced functioning of the federal government. $130 \mathrm{Mr}$. Jackson countered this argument by stating that Supreme Court could on its own resolve "partial adjudications" by biased state judges. ${ }^{131}$ However, even he impliedly conceded that such partiality existed and would harm the administration of federal law. ${ }^{132}$ Thus, they could not, and indeed should not, bear a duty to hear federal business.

A further argument toward mandatory lower federal courts is that of preserving federal authority and supremacy. Though some feared encroachments on state autonomy by the federal government, 133 Hamilton expressed the opposite view: "As to the destruction of State Governments, the great and real anxiety is to be able to preserve the National from the too potent and counteracting influence of those Governments." 134 This fear of state influence, firmly grounded in the experience of federal inefficacy under the Articles of Confederation, ${ }^{135}$ would be

130 STORY, supra note 89, §1604-1605; See Alexander Hamilton, The Examination No. 14, in SeleCted WRITINGS AND SPEEChes of AleXANDER HAMILTON, supra note 86, at 489 (arguing that a federal judiciary without independence would scarcely have the power even to "annoy" the other federal departments); The FEDERALIST No. 78 (Alexander Hamilton), in SELECTED WRITINGS AND SPEECHES OF ALEXANDER HAMILTON, supra note 86, at 181 (noting that an independent federal judiciary is an "indispensable ingredient" in the constitutional plan and that it acts as "the citadel of the public justice and the public security"). In the House debate on the judiciary during the first Congress, Mr. Vining argued not only that the lower federal tribunals were "essential" to fair administration of federal law, but that such power was "in its nature inseparable and indivisible" from the federal power to make and enforce law. 1 ANNALS OF CONG., supra note 63, at 821 (1789). Addressing the counterargument of the lower federal courts' great expense, he noted that, while some expense was concededly necessary, "[t]hey are the price that is paid for the fair and equal administration of your laws." Id.

1311 Annals of Cong., supra note 63 , at 830 .

132 See id. at 829-30.

133 David N. Mayer, The Constitutional Thought of Thomas JefFerson 187 (1994); Brutus No. 15, in 2 The CoMPlete ANTI-FEDERALIST 194 (Herbert J. Storing ed., 1981); see also supra note 51 and accompanying text.

134 Letter from Alexander Hamilton to Edward Carrington (May 26, 1792), in SElected Writings AND Speeches of AleXANDER Hamilton, supra note 86 , at 330 .

135 Letter from Alexander Hamilton to James Duane (Sept. 3, 1780), in 2 The PAPERs OF AleXANDER HAMilton, supra note 66, at 402 ("The idea of an uncontrolable sovereignty in each state, over its internal police, will defeat the 
counteracted by a strong federal judiciary, not limited to merely one Supreme Court. An expanded federal judiciary would be able to thereby protect federal interests more effectively, and act as a barrier to state injustices against individual rights. ${ }^{136}$ Samuel Osgood made the intriguing argument that a stronger federal government was necessary not only to protect against state encroachments on federal power or individual rights, but simply to protect the states themselves from either injustices perpetrated by sister states or foreign powers, which any state alone might lack the power to resist. 137

The necessity of uniformity in adjudicating federal matters was also an important reason to establish a large federal judiciary. In the House debates on the judiciary in the first Congress, Mr. Smith proposed initially that uniformity in interpretation of national law could be achieved by adjudication in state courts and appeals to the Supreme Court directly. ${ }^{138}$ However, he quickly retreated from that position, noting that the constant control by the federal Supreme Court would "dissatisfy the people, and weaken the importance and authority of the State judges." 139 Others similarly argued that state judges could not afford the necessary uniformity of decision and interpretation that consistent, effective federal government required. ${ }^{140}$

other powers given to Congress, and make our union feeble and precarious."); Impartial Examiner No. 5, in 5 THE COMPLETE ANTI-FEDERALIST, supra note 91, at 199 ("It seems to be agreed on all sides that in the present system of union the Congress are not invested with sufficient powers for regulating commerce, and procuring the requisite contributions for all expences, that may be incurred for the common defence or general welfare.").

136 STORY, supra note 89, § 1568; See MAYER, supra note 91, at 261 (noting that, in the context of judicial review, Jefferson favored judicial independence as a safeguard of citizens' rights); James Wilson, Government, Lectures on Law, in 1 The WoRKS OF JAMES WILSON 296-97 (1791) (Robert Green McCloskey ed., 1967) (extolling the necessity and virtues of an independent federal judiciary in effecting the "distribution of justice").

137 Letter from Samuel Osgood to John Adams (Nov. 14, 1786), in 8 The Works of John Adams 419-21 (Charles Francis Adams ed., 1853).

1381 ANNALS OF CONG., supra note 63 , at 798.

139 Id. He went on to argue that the district courts would be ineffectual without greater jurisdictional reach. Id. (" $[\mathrm{I}] \mathrm{t}$ appears that the district court is not clothed with any authority of which the State courts are stripped, but is barely provided with that authority which arises out of the establishment of a National Government, and which is indispensably necessary for its support.”).

${ }^{140} \mathrm{Id}$. ("The necessity of uniformity in the decision of the Federal courts is 
Samuel Livermore of New Hampshire was a particularly vocal opponent of the Judiciary Act of 1789 in which Congress proposed to create lower federal courts distinct from current state courts. ${ }^{141}$ As discussed at the Convention, Livermore again posited that instituting state courts as federal courts would save considerable expense for the new federal government. ${ }^{142} \mathrm{He}$ also propounded the common Anti-Federalist refrain that "lower federal courts, once established, would eventually 'absorb' the state judiciaries, in part because of feared expansive readings of the federal courts' jurisdictional grants." 143 Other debaters shared Livermore's view, although they were a distinct minority.144 Analyzing Federalist opposition to Livermore, Michael Collins has noted that "[c]onstitutional insistence on the creation of lower federal courts is obviously an incorrect understanding of article III' from a modern perspective." ${ }^{145}$ As we will explain in more detail later, however, the modern perspective fails to account for a more nuanced view of compromise, one in which Framer and ratifier intent, and not otherwise plain constitutional language, controlled. For now, it suffices to say that the constitutional necessity of lower federal courts was subject to some debate, but was in general widely accepted for meta-textual political and practical reasons. Here, then, we take Collins's thesis a step further: we argue that lower federal courts were constitutionally mandated, not only because of the inadequacy of state courts but also the institutional, political, and structural benefits they needed to provide to the new federal system.

Other debaters at the First Congress rejoined Livermore's motion to eliminate the lower-federal-courts provision from the Judiciary Act. Madison argued that transforming state courts into federal ones would improperly imbue state judges with life tenure and bypass the nomination process vested in the executive. ${ }^{146}$ This counterargument may be less persuasive in

obvious.").

${ }^{141}$ Michael G. Collins, The Federal Courts, the First Congress, and the NonSettlement of 1789, 91 VA. L. REV. 1515, 1523 (2005).

$142 \mathrm{Id}$. at 1527.

${ }^{143} \mathrm{Id}$. at 1531 .

${ }^{144} \mathrm{Id}$. at 1563-64.

$145 \mathrm{Id}$. at 1544 .

${ }^{146} \mathrm{Id}$. at 1556 . 
light of recent work by Brian Fitzpatrick showing that state courts at the Founding generally employed life tenures during good behavior. ${ }^{147}$ Nevertheless, Madison's point describes the general intuition of the Framers and ratifiers that protecting federal interests required a peculiarly federal judiciary. ${ }^{148}$ Collins provides another, incredibly clear, example of the feeling of constitutional imperative to create lower federal courts:

Gouverneur Morris, who would claim credit for the final draft of Article III at the Constitutional Convention, once said of Article III: "This, therefore, amounts to a declaration, that the inferior courts shall exist.... In declaring then that these tribunals shall exist, it equally declares that the Congress shall ordain and establish them. I say they shall; this is the evident intention, if not the express words, of the Constitution." 149

Collins further identifies that the true debate over the Judiciary Act was not whether Congress could refuse to create lower federal courts, but merely whether state courts would be appointed to do the job in lieu of separate federal courts. ${ }^{150}$ We have further clarified this understanding: not only did Congress lack discretion over whether to create lower federal courts, the significant advantages of institutionally distinct lower federal courts and the disadvantages of constituting state courts as federal tribunals shows that the argument for using state courts was marginal and unpersuasive.

In Haywood, Justice Thomas attempts not only to support state-court jurisdictional freedom but also align this view with the long-standing notion of state-federal concurrent jurisdiction. Concurrency and obligation are, of course, not equivalent, but some highly probative original understandings of state-federal concurrent jurisdiction can support state-court jurisdictional freedom. To support his idea of concurrency, Thomas cites

\footnotetext{
147 See Fitzpatrick, supra note 1, 854-55.

148 Collins, supra note 204, at 1556.

${ }^{149} \mathrm{Id}$. at $1561 \mathrm{n} .175$ (internal citations omitted).

${ }^{150} \mathrm{Id}$. at 1562 .
} 
Hamilton's well-known The Federalist No. 82.151 This writing clearly supports Thomas's reasoning that state courts held a presumptive competency to adjudicate federal matters, since jurisdiction over similar matters was vested in them prior to the creation of the Union. ${ }^{152}$ As such it was not infringed upon absent constitutional mandate otherwise. 153

Yet, a close reading of the Examination No. 6 points out a surprising contradiction in Hamilton's philosophy. In The Federalist No. 82, Hamilton is an outspoken advocate of the states' right to maintain concurrent jurisdiction over federal claims. ${ }^{154}$ Conversely, in the Examination No. 6 Hamilton has a less glowing opinion of the states. Rather than supporting state autonomy, he argues instead that lower federal courts are necessary because of the likely jealousies and prejudices of state judges and the inexpediency of delegating to the state courts "the care of interests which are specially and properly confided to the Government of the United States."155 Hamilton, then, was of the opinion that the states could only tenuously be trusted with important matters. In some of the more foundational arguments supporting republican government, many of the Framers viewed the people at large as prone to vice and passion. ${ }^{156}$ Here, similarly, the Framers were loath to entrust federal matters to state provincialism. The federal government, by contrast, was composed of carefully selected and virtuous men. They would steer the vessel of the nation through the tumultuous storms of state prejudice and infighting. This view, the view that

${ }^{151}$ Haywood, 129 S. Ct. at 2120 (Thomas, J., dissenting).

$152 I d$. at $2120-21$.

153 This power, apparently, did not fall prey to the "big bang" rule that struck down other state powers at the adoption of the Constitution. See U.S. Term Limits v. Thornton, 514 U.S. 779, 803 (1995) (concluding that some original state powers were sacrificed in the creation of the Union). At least, the matter is not discussed by Justice Thomas.

154 See The Federalist No. 82, at 553 (Alexander Hamilton) (Jacob E. Cooke ed., 1961).

155 Alexander Hamilton, Examination No. 6, in 25 THE PAPERS OF ALEXANDER HAMILTON, supra note 66, at 487.

156 See generally James Madison, Vices of the Political System of the United States, in 9 THE PAPERS OF JAMES MADISON 348 (Robert J. Brugger ed., Univ. Press of Virginia 1987) (arguing that the States violate federal authority, treaties, and interstate agreements, as well as commit injustices, and the people themselves are susceptible to sweeping passions resulting in mob rule). 
concurrency might not be as clearly inherent in our judicial system as Thomas believes, underscores the idea of jurisdictional freedom. It merely comes to that destination by a different road. Instead of giving such freedom out of respect for state autonomy, some Framers sought to restrict state-court adjudication of federal rights to protect federal rights from the state bias and vice.

Although the Madisonian Compromise did in fact win the day at the Convention, the implications drawn from this occurrence are not as clear as the literature portrays them. ${ }^{157}$ For Thomas specifically, arguments in favor of mandatory lower federal courts would have aided his ultimate goal of eliminating state-court burdens to hear federal matters. If lower federal courts were mandatory, one could argue that states should be allowed to refuse federal business, since there would always be a federal forum ready to hear the claims. ${ }^{158}$ Further, a view that lower federal courts were required could be used to show that the Founders may not have wanted the states to hear federal claims, but instead sought to divest them of such power by creating a forum for federal business. Perhaps Thomas thought it was more desirable to establish both state competency toward federal claims and a lack of power to compel to such jurisdiction. Thomas, then, wanted to have it both ways: state courts can hear federal claims, but don't have to if they don't want to. Trying to preserve both claims led him to proffer less persuasive arguments for each.

A strong federal judiciary equipped with lower courts was a generally popular view. ${ }^{159}$ Whether to protect individuals or the

157 See Collins, supra note 54, at 61-62 (noting that some among the Framers believed that lower federal courts were constitutionally required). Collins later discusses the debates in the first Congresses over the possibility that lower federal courts were constitutionally mandated. Id. at 69.

158 This is indeed one of the normative arguments that can be used to combat compelled state jurisdiction over federal claims today. Since federal courts have long been a fixture of the federal government, and are not likely to be abolished any time soon, states should have greater freedom to refuse federal claims that have their own tailor-made forum. See Jordan, supra note 23.

1591 ANNALS OF CONG., supra note 63 , at 822 ("It is conceded on all hands, that the establishment of [lower federal courts] is immutable."). Id. at 798 ("With respect to the first point, it seems generally conceded that there ought to be a district court of some sort. The constitution, indeed, recognises such a 
federal government from the states, the ideals of federalism practically demanded a federal judiciary that could counterbalance both its coordinate departments and its sister courts in the states. This finding destabilizes Thomas's conclusions regarding state-court concurrency. It undermines his assertion that state-court concurrency was "essential" to the Madisonian Compromise's formulation that allowed, but did not require, lower federal courts. ${ }^{160}$ Since lower federal courts were essentially guaranteed in the minds of the Framers and ratifiers, the states may not have been indispensable arbiters of federal law. Indeed, the Framers' evident distaste for state-court adjudication of federal matters suggests that they meant to reduce, if not totally divest, the state courts of concurrent jurisdiction through the lower federal courts. ${ }^{161}$

We should make it clear here that the existence of dissenting views identified in the discussion above does not in itself destabilize our thesis. We are not attempting to make the arguments in favor of lower federal courts for the Framers. Rather, we have tried to catalogue the various arguments both for and against and have determined that the most popular view, and the one embodied in the true Compromise, included mandatory, distinct lower federal courts.

\section{Article I and Congressional Prerogative}

James Pfander has argued that, notwithstanding jurisdictional freedom that may be read into Article III or the Supremacy Clause, Article I empowers Congress to require state courts to entertain federal claims. ${ }^{162}$ Under his interpretation,

court, because it speaks of 'such inferior courts as the Congress shall establish;' and because it gives to the Supreme Court only appellate jurisdiction in most cases of a federal nature."). Mr. Morris claimed that the apportionment of jurisdiction gave Congress a "duty" to create lower federal courts to adjudicate those matters outside the Supreme Court's appellate jurisdiction. 11 ANNALS OF CONG. 86 (1802).

160 Haywood v. Drown, 129 S. Ct. 2108, 2120 (2009) (Thomas, J., dissenting).

161 See supra notes 71-72 and accompanying text.

162 James Pfander, Federal Supremacy, State Court Inferiority, and the Constitutionality of Jurisdiction-Stripping Legislation, 101 Nw. U. L. Rev. 191, 212 (2007). 
the "ordain and establish" language of Article III cannot easily accommodate the incorporation of existing state courts as federal tribunals. ${ }^{163}$ Instead, Pfander relies on Article I, section 8, which gives Congress the power "to constitute Tribunals inferior to the supreme Court."164 This power, coupled with the Necessary and Proper Clause, gives Congress the authority to forgo creating lower federal courts outright. 165 They could alternatively choose to "constitute" state courts as federal tribunals. ${ }^{166}$ Indeed, analysis of the Madisonian Compromise may support this view, because Madison's reworked proposal for lower federal courts allowed the legislature to "appoint inferior Tribunals," which in context appeared to suggest "formally enlisting state courts for national purposes." 167

While this reading solves the apparent redundancy problem between Article I and Article III, 168 it ignores three powerful counter-arguments. First, as explored above, the Madisonian Compromise left Congress discretion to create or not create federal courts in name only. Their true duty was to create such necessary courts to uphold federal supremacy, secure individual rights from state intrusions, and accommodate state sovereignty and state-court competency concerns. He relies heavily on Hamilton's account of the role of the Inferior Tribunal Clause as laid out in The Federalist No. 82.169 There, Hamilton argued that state courts might be adopted as lower federal courts. ${ }^{170}$ But even Hamilton recognized that Congress had at least a "two-fold power": either institute state courts as federal courts or "create new [federal] courts with a like power." 171 Further, he thought it "absurd" that new federal courts would displace existing state courts. ${ }^{172}$ In the end, Hamilton did more in The Federalist No. 82 to assuage critics of the plan for the national judiciary than to actually advocate for utilizing state

\footnotetext{
${ }^{163} I d$. at 203.

164 U.S. Const. art. I, § 8, cl. 9.

165 Pfander, supra note 244, at 205.

$166 I d$.

167 Liebman \& Ryan, 717.

168 Pfander, supra note 244, at 205.

${ }^{169} I d$. at $216-19$.

170 The Federalist No. 82 (Alexander Hamilton).

171 Pfander, supra note 244, at 217.

$172 I d$. at 218.
} 
courts as federal tribunals. An ardent supporter of the federal government, 173 Hamilton's move was consistent with the pragmatic approach the Constitution's supporters had to take to avoid derailing ratification.

Second, and far more concerning, is Pfander's failure to account for the function of Article I. It goes without saying that Congress exercises limited powers. ${ }^{174}$ To act within its constitutional authority, Congress take express, positive action. As Pfander acknowledges, the current concurrency presumption is only an implicit action under Congress's Article I power. Why is implicit power so clear and strong in this instance? There are no satisfactory answers. For example, as a matter of policy, a concurrency presumption does not protect federal regulatory sovereignty but undermines it by giving states a voice in the exposition of federal law.

The third reason to doubt Congress's Article I power to oblige state courts to hear federal business relates to Pfander's own formulation of that power. To constitute state tribunals as federal ones, Congress should "simply take state courts as it finds them, constitute them as tribunals for certain federal purposes, and avoid structural problems." 175 Congress might also "pay the states directly to defray the cost of its relying on such tribunals rather than being constrained to pay the judges directly, as it must under Article III."176 Congress has done neither of these things. As cases like Brown, Dice, and others show, federal rights are accompanied by federal procedures that states must apply. ${ }^{177}$ And, while a funded-mandate approach to state-court obligation seems consistent with Congress's Supremacy Clause powers, our reading of the jurisdictional-substantive compromise embodied in the constitutional debates provides solid ground on which states may refuse such a mandate. Even though funding would make the obligation less burdensome, states have the constitutional space to refuse such obligations outright.

173 David McGowan, Ethos in Law and History: Alexander Hamilton, the Federalist, and the Supreme Court, 85 MinN. L. REV. 755, 879 n.579 (2001).

174 See United States v. Lopez, 514 U.S. 549, 566 (1995).

175 Pfander, supra note 244, at 222.

176 Id. at 204.

177 Brown v. W. Ry. of Alabama, 338 U.S. 294, 298 (1949); Dice v. Akron, Canton, \& Youngstown R. Co., 342 U.S. 359, 363 (1952); Felder v. Casey, 487 U.S. 131, 138 (1988); but see Johnson v. Fankell, 520 U.S. 911, 918 (1997). 


\section{INDETERMINACY AND COMPROMISE}

There is no controversy in claiming that compromise was a part of the Founders' constitution-making process. The context in which the Framers and ratifiers lived was one of intense debate and bitter rivalry between those who believed in the necessity of strong national government and those who feared the subjugation or dissolution of the states under a domineering federal sovereign. The classic view holds that hallmark compromises such as the Madisonian Compromise did not resolve the issues raised in debate. Rather, the compromise was that entrusted Congress with the discretion to resolve the debate later. While this view accounts for the exigencies of ratification, another theory is supported by the historical account and modern theories of intentionalists originalism. Leveraging those theories, we argue that constitutional compromises were not always geared toward pushing off resolution of a debate, but rather that the language of certain clauses were left in the form proposed by the Convention in order to avoid delaying ratification further. Thus, while their plain language invites the superficial reading that the debate was preserved for post-ratification actors, Framer and ratifier intent shows that many such controversies were resolved preratification, vesting Congress with the mere duty to implement the result reached. This is precisely the view we have advocated above with respect to the constitutional provisions underlying state-court jurisdictional compulsion. Before describing this theory of counter-textual intentionalism, we will first explore the limitations in current originalist doctrine. We will then describe why compromise was a critical element in constitution-making. Finally, we will connect up the need compromise with the notion that some compromises resulted in counter-textual yet firm commands from the Framers and ratifiers.

\section{A. Originalism's Indeterminacy}

The significant limitations of originalist methodology must be recognized if the spirit of honest, rigorous scholarship may be attributed to its adherents. ${ }^{178}$ Perhaps the most fundamental

178 See ACLU of Ohio, Inc. v. Taft, 385 F.3d 641, 651 (6th Cir. 2004) 
assumption underlying originalism is that there is a cohesive, discoverable "original meaning" that inheres in the Constitution. The Framers were so numerous and expressed such diversity of opinion that a majority, let alone a consensus, on any particular issue is hard, if not impossible, to determine. ${ }^{179}$ Even originalunderstanding originalism suffers from a crippling reliance on normative assumptions about the competency and beliefs of their supposed late-eighteenth-century "reasonable person."180 This lack of cohesion casts a long shadow over the achievements of originalism as a source of constitutional interpretation. Without a reasonable majority or a principled objectivity in selecting the "interpreter" of constitutional language, the cohesive original meaning that transcends from the Founding to our day loses much of its luster.

This evident lack of cohesion spawns another, more troubling problem. Selective citation of Founding-era sources can support almost any constitutional interpretation. ${ }^{181}$ A spirit of

(pointing out that "neither constitutional 'textualism,' 'originalism,' or any other interpretive 'ism' requires [the interpreter] to abandon all common sense and reasonableness").

179 Whittington, supra note 14, at 605 (noting that one major criticism of originalism is that there is not a definite, coherent intent that can be gleaned from the "varying intentions" of the many Framers); Lawrence B. Solum, $A$ Reader's Guide to Semantic Originalism and a Reply to Professor Griffin, ILL. PUB. L. RES. PAPER No. 08-12 at 4 (2008) ("[T] he multiplicity of framers creates problems of conflicting intentions.").

180 Robert W. Bennett, Originalism and the Living American Constitution, in RoberT W. BENNETT \& LAWRENCE B. SOLUM, CONSTITUTIONAL ORIGINALISM: A DEBATE 107 (2011). Lawrence Solum counters that conventional semantic meanings exist independently of "psychological states of particular persons on particular occasions." Lawrence B. Solum, Living with Originalism, in ROBERT W. BennetT \& LaWrence B. Solum, Constitutional Originalism: A DeBate 147 (2011). In this argument, he may be referring to a specific level of generality at which we assess "conventional" meaning. We respond to this contention in Part III and argue that particular psychological states are important to understanding compromise: we must understand the particular intentions of the Framers and ratifiers as they crafted the Constitution to understand the intended application of its provisions.

181 See generally D.C. v. Heller, 554 U.S. 570 (2008) (primary opposing sides leverage Founding-era sources, particularly dictionaries and other sources illuminating Founding-era linguistic norms). This sort of back-andforth originalist snow-ball fight clouds the issue at hand: we seemingly cannot, for particularly contentious issues, elucidate a clear message from the Framers as to which interpretation is correct. This is because, in general, if an issue is 
scholastic honesty mandates that originalists acknowledge and respect the ambiguities, uncertainties, and unresolved conflicts at the Founding. ${ }^{182}$ Professor Kramer suggests that originalists take account of all sources from the Founding, including sensational rhetoric from the ratification debates, instead of blindly relying on the more venerable sources like Madison, Hamilton, and Jefferson. ${ }^{183}$ After all, they were merely a part (albeit an important one) of the process of formulating the lateeighteenth-century-American context that created the original public meaning that originalists seek. ${ }^{184}$

Relying on a broad review of Founding-era sources, rather than a selective analysis, helps solve further problems with originalist methodology. Arguments similar to the one we have made here have also been made in relation to the textualist slant of "new originalism."185 Both types of originalism suffer the same ultimate dilemma: where multiple sources are legitimate and support opposite or inconsistent conclusions, which should we choose? ${ }^{186}$ Alicea and Drakeman posit that

In this kind of case, where the text, read in light of all the tools in the New Originalists' kit, leads to a semantic "tie," it is at least conceivable that a sufficiently clear understanding of the provision's meaning to the Framers can be found in the records

particularly contentious today, as with the 2nd Amendment in Heller, the issue was likely contentious at the Founding, admitting huge diversity of opinion and reasoned arguments on all sides. See Evan H. Caminker, State Sovereignty and Subordinacy: May Congress Commandeer State Officers to Implement Federal Law?, 95 CoLUM. L. REV. 1001, 10081995 ("The proper scope of federal authority has been in dispute since the Framing-and so, too, has been the proper role of states within that realm of federal authority.").

182 Kramer, supra note 1, at 1651-52.

${ }^{183}$ Id. at 1653; see also Whittington, supra note 14, at 609 (observing that "new originalism" is less focused on the "concrete intentions" of the Framers and more on the "public meaning" of the Constitution at its ratification).

${ }_{184}$ Kramer, supra note 1, at 1653-54; MARCOSSON, supra note 1, at 128 (calling the Framers "grossly unrepresentative of the population for whom the established a government").

185 Alicea \& Drakeman, supra note 39 ("[The] array of inconsistent uses of the key constitutional language creates a methodological conundrum for New Originalists quite similar to the 'summing' problem they have linked with Old Originalism.")

${ }^{186} \mathrm{Id}$. at 57 . 


\section{of the Philadelphia Convention and the state ratifying conventions. 187}

If only things were so simple. As we have admitted, it appears we cannot rely on the Framers, ratifiers, or anyone else in the eighteenth century to give us the straight answer on what a particular clause meant.

Acknowledging that originalism has some limited value in illuminating constitutional meaning, it does not follow, as Thomas would have it, that the Framers' intended meaning is the right one. ${ }^{188}$ Whatever may be said about their intellectual, philosophical, or moral virtues, the Framers did not survive to the present day, nor receive portentous visions of the future which allowed them to craft a timeless document. ${ }^{189}$ Many of the Framers themselves cautioned against undue deference to their views in constitutional interpretation. ${ }^{190}$ Some even feared that

${ }^{187}$ Id. at 64.

188 Kramer, supra note 1, at 1635 (questioning reliance on the Founding by arguing that the Framers themselves recognized "governing as a process shaped by experience" and that the Constitution "must be accommodated to lessons learned in practice").

189 Balkin, supra note 17, at 435 ("The accumulation of these constructions over time, as one innovation builds on another, produces a sort of institutional evolution; it has a path dependence that drives constitutional development forward in ways that no one in 1787 would have predicted.").

190 See Letter from James Madison to Thomas Ritchie (Sept. 15, 1821), in 9 The Writings OF JAMES MADISON, supra note 119, at 72 ("As a guide in expounding and applying the provisions of the Constitution, the debates and incidental decisions of the Convention can have no authoritative character. However desirable it be that they should be preserved as a gratification to the laudable curiosity felt by every people to trace the origin and progress of their political Institutions, \& as a source perhaps of some lights on the Science of Govt. the legitimate meaning of the Instrument must be derived from the text itself; or if a key is to be sought elsewhere, it must be not in the opinions or intentions of the Body which planned \& proposed the Constitution, but in the sense attached to it by the people in their respective State Conventions where it recd. all the Authority which it possesses."); THE FEDERALIST No. 38 (James Madison) (Jacob E. Cooke ed., 1961) (reasoning that the errors inherent in the document may have come from lack of experience on the part of the Convention, and that, "on this complicated and difficult subject," the problems and their answers "will not be ascertained until an actual trial shall have pointed them out?"); THE FEDERALIST No. 82 (Alexander Hamilton) (Jacob E. Cooke ed., 1961) ("Tis time only that can mature and perfect so compound a system, can liquidate the meaning of all the parts, and can adjust them to each 
unthinking deference to Framer intent in the future would be dangerous to liberty. ${ }^{191}$ Originalism's limitations highlight its imperfect relevance in today's world. ${ }^{192}$ Thomas himself has admitted as much. ${ }^{193}$

The vital issues of federalism underlying the Haywood majority and dissent underscore the effects of changed circumstances. The majority and the line of "valid excuse" cases they cite support the proposition that state courts are competent to hear federal claims alongside federal courts. 194 Some Founders argued for such parity because they foresaw the downfall of the states to the dominance of the federal government.195 The same principle was leveraged in Haywood to not only allow, but indeed

other in a harmonious and consistent WHOLE"); STORY, supra note 89, § 407, at $391 \mathrm{n} .1$ (disparaging the notion of constitutional interpretation by assessing the '"probable meaning' to be gathered by conjectures from scattered documents, from private papers, from the tabletalk of some statesmen, or the jealous exaggerations of others") (emphasis in original); Letter from Thomas Jefferson to Samuel Kercheval (July 12, 1816), in The Political WRiTings OF THOMAS JEFFERSON, supra note 84, at 123-25 (insisting that "periodical repairs" to the Constitution would prevent the United States from "falling into the same dreadful track" as European monarchs, whose inability to "wisely yiel[d] to the gradual change of circumstances" proved disastrous for them and their people); see also H. Jefferson Powell, The Original Understanding of Original Intent, 98 HARV. L. REV. 885, 948 (1985) (arguing that no interpretational method employed by the Framers was analogous to "modern notion of intentionalism," and that instead early courts and scholars "applied standard techniques of statutory construction to the Constitution").

191 James Iredell, North Carolina Ratifying Convention Debates, in 4 ELLIOT'S DEBATES ON THE FEDERAL CONSTITUTION, supra note 154, at 149.

192 Whittington, supra note 14, at 605-06 (noting the "dead hand" problem of originalist argument).

193 Brown v. Entm't Merchs. Ass'n, 131 S. Ct. 2729, 2759 (2011) (Thomas, J., dissenting) (conceding that "the original public understanding of a constitutional provision does not always comport with modern sensibilities" and "may also be inconsistent with precedent").

${ }^{194}$ Haywood v. Drown, 129 S. Ct. 2108, 2114 (2009).

195 See The Federalist No. 6 (Alexander Hamilton) (Jacob E. Cooke ed., 1961) (concluding that a constitution uniting the states would "preven[t] the differences that neighbourhood occasions, [and] extinguish[h] that secret jealousy, which disposes all States to aggrandise themselves at the expence of their neighbours"); THE FEDERALIST No. 10 (James Madison) (Jacob E. Cooke ed., 1961) ("[S]tates must be protected as separate political entities so that they can serve as countervailing sources of power and reservoirs of liberty"); see also supra note 91 . 
require state court adjudication of federal claims. ${ }^{196}$

Originalism can accommodate changed circumstances, though not without cost. Instead of looking for the consistency and concurrence that never existed at the Founding, originalists should instead focus on leveraging originalism as just another form of legal reasoning. ${ }^{197}$ This may not be the most satisfying answer for those truly dedicated to interpreting the Constitution as the Founders would, 198 but it is the only honest route available.

Accepting the view that originalist reasoning is akin to any other form of legal reasoning implicates two assumptions that originalism should carry with it. 199 First, originalists must accept that there is disagreement among Founding-era sources and acknowledge that they merely argue in favor of one possible interpretation. $^{200}$ They cannot attempt to solidify their conclusions as representative of unanimous consent among the Founding generation. Second, they must expand their arguments beyond the scope of the Founders. In fact, Thomas does an

196 Haywood, 129 S. Ct. at 2117.

197 See infra notes 212-215 and accompanying text.

198 Alicea and Drakeman argue that such selectivity is what powers the current policy-driven use of originalism. Alicea \& Drakeman, supra note 39, at 60 .

${ }^{199}$ In this point we fully accept Larry Kramer's words of caution, that the advocacy that underlies legal training must be somewhat curtailed when approached historical analysis. Larry D. Kramer, When Lawyers Do History, 72 GEO. WASH. L. REV. 387, 402 (2003). He summarizes his lesson thus:

An injunction on advocacy is really about avoiding distortion. It is about recognizing the difference between making an argument and pushing it too far, between defending one's conclusions reasonably and misleading readers into thinking that support for one's position is stronger than may in fact be Id. the case.

200 Thomas Jefferson himself supported this view, which is clearly contrary to Thomas's supposedly neutral approach by which he acts merely as a vessel for the opinions of the Framers. Letter from Thomas Jefferson to John Adams (Feb. 25, 1823), in 15 The Writings of Thomas JefFerson 421 (Andrew A Lipscomb \& Albert Ellery Bergh eds., 1905) ("[M]ultiplied testimony, multiplied views will be necessary to give solid establishment to truth. Much is known to one which is not known to another, and no one knows everything. It is the sum of individual knowledge which is to make up the whole truth, and to give its correct current through future time.”). 
admirable job of this in Haywood. After arguing his positions from an originalist perspective, he "accept[s] the entirety of the Court's precedent in this area" and sets himself up for arguments alternative to originalism. ${ }^{201}$ To that end, he presents theoretical arguments about the dichotomy between substantive and jurisdictional laws, noting that the New York statute at issue in the case operates jurisdictionally and thus cannot discriminate against federal claims. ${ }^{202}$ Nevertheless, our disagreement with Thomas is focused on his failure to both recognize the fallibility of his originalist analysis and accept even broader non-originalist notions such as changed circumstances. His overzealous dedication to originalism foreclosed him from leveraging his full potential arsenal against the majority.

Grudging, if implicit, acknowledgement of this reality has already begun in the originalist academy. Lawrence Solum touts the "interpretation/construction" distinction as indicative of a more effective "new" originalism. ${ }^{203}$ This theoretical maneuver distinguishes between interpretation, which involves the bare, practically objective process of ascertaining the original public meaning or Framer view of a word or clause, and construction, which acts where real facts require an application of constitutional text that is not clearly resolved by interpretation. ${ }^{204}$ Where the result of this inquiry is clear and unambiguous, that meaning controls. ${ }^{205}$ Where the result is vague or ambiguous, originalists must ply the "construction zone." 206 Here, they still claim to be bound by the interpretation they've discovered, but are more free to develop divergent views of what non-originalist normative or theoretical frameworks will help them determine a final application of constitutional language. ${ }^{207}$

201 Haywood v. Drown, 129 S. Ct. 2108, 2133 (2009) (Thomas, J., dissenting).

202 Id. at 2133-34. This final point in Thomas's argument reflects one of the several normative and theoretical reasons why we ultimately support Thomas's conclusion. See supra note 9.

203 Solum, supra note 42 , at 22-24.

$204 I d$. at 23.

$205 I d$.

$206 \mathrm{Id}$. at 69.

${ }^{207} \mathrm{Id}$. at 25-26, 70. 
Such a method "makes a mountain out of a molehill."208 How many clear, unambiguous answers can the Constitution provide? Even simple requirements like the minimum-age requirement for the Presidency can be subject to ambiguity. ${ }^{209}$ Inviting pluralism in construction undermines originalism's objectivity, which for many is its primary appeal. ${ }^{210}$ While this means that originalism must necessarily prove far less than its adherents hope, it is the right move. Our proposed view of originalist analysis accepts the reality that interpretation is illuminative but not necessarily controlling. By incorporating originalist interpretation as one element of constitutional interpretation, we eviscerate originalism's unwarranted claims to principled finality and preserve only those elements of originalism that forthrightly contribute to the vast, diverse mural of constitutional meaning.

\section{B. The Need for Compromise}

Utilizing a methodology that acknowledges both the contributions and limitations of the originalist methodology, we can now show how a broad survey of Founding-era sources shows that constitutional compromise did not end at the ratified text. Instead, it extended beyond the text and into the infant years of the republic.

There are a number of reasons that anyone interested in truthful constitutional interpretations should be attracted to this idea. First, traditional originalism can ignore important possible sources of illumination. By focusing on the enacted text, originalists necessarily overlook the practical aspects of

208 Solum, supra note 69, at 156.

209 Bennett, supra note 69, at 85-86. We return to this clause later to further illustrate the need for intentionalism and its role in forming countertextual compromise.

210 Id. at 97, 103; see also Alicea \& Drakeman, supra note 39, at 5 (describing the primary difference between "Old" and "New" originalism as a shift away from intentionalism and toward "the objective meaning of the text itself"). Justice Thomas often straddles this divide by purporting to be a strict textualist while inviting the "plain meaning" of such text as it was understood by the Framers. Nancie G. Marzulla, The Textualism of Clarence Thomas: Anchoring the Supreme Court's Property Rights Jurisprudence to the Constitution, 10 AM. U. J. GENDER SOC. POL'Y \& L. 351, 362 (2002). 
constitution-making, particularly compromise that extended beyond the text. For those exploring the Constitution, every word and source is vital to exploring what was and was not included in the final text and why. Thus, we cannot ignore the nature of political expediency and how it affected the framing and ratification of the document.

The ratification of the Constitution was anything but a sure thing at the time of its framing and ratification. ${ }^{211}$ Many were interested not only in amending the document sent to them from the Convention, but even in tossing out the whole project and beginning anew. ${ }^{212}$ The Framers took many months to agree on a final form for the document. The Confederation Congress was in heated disagreement as to whether they could propose amendments to the text or if they were simply charged with approving the document for transmission to the state ratification conventions. ${ }^{213}$ Even more concerning was the debate over whether the ratification debates themselves could propose or even demand amendments. ${ }^{214}$

This is the heart of the "all-or-nothing" notion that the Federalist supporters of the Constitution put forward. ${ }^{215}$ They argued that a federal government was urgent and vital to protect the United States from foreign interference. ${ }^{216}$ Delay might cost the newly-freed nation everything. The Federalist response to the Albany Antifederalists' influential circular put the point eloquently:

THE GRAND AMERICAN UNION has already encircled us except on the one side where our haughty enemy still bleeds with the wounds of our conquest; and on the other a defenseless seacoast

211 Pauline Maier, Ratification: The People Debate the Constitution, 1787-1788 68-69 (2010).

212 Id. at 76.

${ }^{213} I d$. at $52-59$.

${ }^{214} I d$. at 59, 295-96, 61-62, 105; see also id. at 118 (noting that some ratifiers insisted on recommending amendments even if they themselves could not amend the proposed text).

${ }^{215}$ Id. at 68-69 (finding that the Constitution's supporters' plan was to "go for broke" and work to get the Constitution quickly adopted without delaying amendment proposals).

${ }^{216} I d$. at 261 . 
invites the avarice of an adventitious invader. Our neighbors and friends extend their arms to embrace us - UNITE then, ye lovers of our common county. ${ }^{217}$

Furthermore, continued debate on the content of the Constitution would only lead to further confusion, disagreement, and possibly endless delay in forming a new government. ${ }^{218}$ If some states required pre-ratification amendments while others did not, Edmund Randolph feared it could mean "inevitable ruin to the Union." 219 Even Charles Pinckney, who "disliked parts of the Constitution," recognized that "only 'confusion and contrariety' could result from letting the state recommend amendments to the Constitution." 220

Nevertheless, many Anti-federalists and state convention speakers dismissed the urgency of the Federalist's plea. ${ }^{221}$ Instead, they proposed many changes to the text which they expected Congress to consider carefully. ${ }^{222}$ Some gave only conditional ratification that was dependent on certain amendments being adopted. ${ }^{223}$ They asserted that, as the true and ultimate sovereigns of the United States, they could not be forced to accept a Constitution that was not of their design. ${ }^{224}$ Others still called for a second convention, either to review the states' various proposed amendments or start the project over from scratch. 225

\section{The Intentionalist Thesis Revisited}

This volatile environment demanded a pragmatic approach from those who wanted to see the current Constitution ratified

217 The 35 Anti-Federal Objections Refuted, by the Federal Committee of the City of Albany, April 1788.

218 MAIER, supra note 109, at 446, 302, 117.

${ }^{219} I d$. at 261 . John Jay similarly opposed conditional ratification, arguing that because some states were "content with [the Constitution] as is," preratification amendments by other states would lead to a divisive second convention. Id. at 337.

$220 I d$. at 45 .

${ }^{221} I d$. at 231.

${ }^{222}$ Id. 48-49, 398, 302, 421, 45, 261, 117.

${ }^{223}$ Id. 379-80.

${ }^{224} \mathrm{Id}$. at 48,89 .

${ }^{225} \mathrm{Id}$. at 391, 397. 
and not mired in further amendment proposals or a second convention. In the interest of ratification, supporters on both sides made difficult but important compromises in the constitutional text that affected not only the meaning of otherwise plain language, but also shunted responsibility for important elements of government off to later actors, including Congress. Such an idea undermines the constitutional finality that originalists so desire, because compromises that pushed compromise realization to later generations are just as critical to constitutional interpretation as issues that were clearly resolved in the final text.226 Any full account of original constitutional meaning must acknowledge that post-ratification realities helped enunciate the constitutional vision of the Framers and ratifiers that could not, for practical purposes, be included in the Constitution's ratified text. 227

Moreover, the idea of proposed amendments was typically closely aligned with compromise that extended post-ratification. The Bill of Rights is the clearest example of this practice. Many ratifiers acknowledged the necessity of ratifying the document as it stood. ${ }^{228}$ Their assent to ratification was thus vitally dependent on Article V and its amendment processes. ${ }^{229}$ Their understanding of the Constitution at the time of ratification, then, was one that included a clear need for post-ratification dialogue, development, and Congressional action. Congress did its duty by quickly proposing the first ten amendments to the Constitution. ${ }^{230}$ We would argue that such a compromise is equally important to any compromise struck in the text itself.

This view at first blush appears quite similar to the orthodox interpretation of such grand compromises as the Madisonian Compromise. We propose a different view of the nature of that and other compromises, as discussed in greater detail below. Instead of the traditional view which vested discretion in later actors to act consistently with the broad themes of the Constitution, here we argue that the clauses

226 EdWARD A. PURCELl, JR., ORIGinAlism, FEDERALiSM, AND the AMERICAN CONSTITUTIONAL ENTERPRISE: A HISTORICAL INQUIRY 5, 25 (2007).

227 See Solum, supra note 42 , at 53.

228 See supra notes 113-116 and accompanying text.

229 See MAIER, supra note 109, at 48-49, 397.

230 Maeva Marcus, Speech, The Adoption of the Bill of Rights, 1 WM. \& MARY BILL RTS. J. 115, 118 (1992). 
operative on state-court jurisdictional obligations were in fact mostly settled by the Framing and ratifying conventions. Their debates acknowledged opposing views of the extent of effectual federal power and the need to preserve state sovereignty. In the end, lower federal courts were deemed necessary to strike a proper balance between national and state governments, but the Supremacy Clause and other clauses were construed in a very limited fashion in order to protect states from consolidation or domination under the new federal government. Particularly in the context of Article III, these compromises did not, as many uncritically conclude, mean that Congress had unlimited discretion to refuse to create lower federal courts. Counter to the otherwise plain meaning of Article III, the Framers and ratifiers accepted the text of that clause for prudential and practical reasons, all the while understanding that the real compromise was concluded and only its implementation was left to Congress.

At this point we should address an issue that will be clear to many readers after reading the previous Part: why the focus on Framer and ratifier intent? "New" originalism touts the objectivity of original public meaning as a more principled way to approach constitutional interpretation. ${ }^{231}$ Nevertheless, modern intentionalists roundly pan the alleged "objectivity" of this new approach, and it is this supposed objectivity that stands in the way of our counter-textual readings of Article III and the Supremacy Clause.

In a recent work defending and criticizing contemporary iterations of originalist methodology, Larry Alexander and Stanley Fish offer convincing arguments based in linguistic theory that Framer and ratifier intent is the only legitimate source for originalist interpretation. ${ }^{232}$ First, Fish notes that there cannot logically be meaning without intention. ${ }^{233}$ Any author intends the signs and symbols he uses to embody a particular meaning based on his circumstances, his audience, and a number of other factors. ${ }^{234}$ Such signs carry no meaning

231 Solum, supra note 42 , at 13-14.

232 The Challenge OF ORIGINALisM: THEORIES OF CONSTITUTiOnAL INTERPRETATION (Grant Huscroft \& Bradley W. Miller eds., 2011).

233 Stanley Fish, The Intentionalist Thesis Once More, in THE CHALLEngE OF ORIGINALISM: THEORIES OF CONSTITUTIONAL INTERPRETATION 102 (Grant Huscroft \& Bradley W. Miller eds., 2011).

234 Id. at 101. 
whatsoever prior to their deployment in a purposive act of communication. ${ }^{235}$ In other words, an author's meaning is the true meaning of the text, notwithstanding what message is communicated or miscommunicated to the reader. ${ }^{236}$

Fish acknowledges that an author's intention to deploy the original public meaning of the words he uses may be a default assumption. ${ }^{237}$ However, he counters that such an assumption must be argued for. ${ }^{238}$ The author's intention to either use or flout conventional meanings is never apparent from the text itself. ${ }^{239}$ Thus original public meaning is just one possibility within a world of possible authorial intent.

One example Fish provides is the distinction between commonplace and poetic language. Whereas an author's intent to deploy commonplace meanings is consistent with original public meaning, the author's choice to use a poetic style of language, one in which meaning is not apparent from the text itself but instead hidden for the reader to discover, is not. ${ }^{240}$ This example highlights a part of Fish's intentionalists thesis that is critical to our argument: "[s]traightforwardness and ambiguity are the properties not of language, but of intentions." 241 The only way to resolve the question of whether a text is ambiguous or straightforward is to approach it with assumptions about the author's intention to use language in a straightforward or ambiguous manner. ${ }^{242}$

An example here will help illuminate the importance of this principle. Consider the Presidential age requirement: "neither shall any Person be eligible to [the office of President] who shall not have attained to the Age of thirty five Years." 243 Enumerating a numerical value would appear to be immutable. ${ }^{244}$

$235 I d$.

${ }^{236} I d$. at $101-02$.

${ }^{237} I d$. at 107.

${ }^{238} I d$.

${ }^{239} \mathrm{Id}$. at $103,107$.

$240 \mathrm{Id}$. at 112 .

${ }^{241} I d$.

242 Id. at 113.

${ }^{243}$ U.S. ConST. art. II, § 1, cl. 4.

${ }_{244}^{24 d a m ~ M . ~ S a m a h a, ~ L o w ~ S t a k e s ~ a n d ~ C o n s t i t u t i o n a l ~ I n t e r p r e t a t i o n, ~} 13$ U. PA. J. CONST. L. 305, 312 (2010) ("[T] he age requirement for presidents is one of countless points of constitutional law on which a practical consensus holds across competing interpretive methods."). 
However, the clarity of such a phrase is absolutely dependent on the intentions of the author to choose this meaning. It is at least conceivable, with admittedly some creativity, that the Framers and ratifiers intended the numerical requirement to represent an age of maturity commensurate with the requirements of the presidential office. ${ }^{245}$ One need not even accept that the authors intended such a counter-textual meaning in order to recognize the heart of the matter, that even conventional meanings originate only in intention.

Solum would argue that original public meaning is still a legitimate source for interpretation because the Framers and ratifiers must have intended to use the conventional meanings of their day. ${ }^{246}$ This would promote clearer understanding of the text at the time of ratification and aid later readers in interpretation because such meaning is supposedly readily ascertainable. But our account of the exigencies of compromise counters this view: despite any supposed concern for clarity, the Constitution's supporters' overriding concern was with ratification. Clarity would certainly have been the ideal. It would have provided later interpreters with clear textual commands. Nevertheless, the desire for successful adoption of the Constitution required that the Framers and ratifiers set desires for clarity aside in the interest of pushing the document through the state ratifying conventions. Because of this dominant concern, we cannot assume, as Solum would, that the Framers and ratifiers unequivocally supported interpretation consistent with the conventional meanings of their words at the Founding. We argue instead that they employed a non-standard set of meanings for the words they used that preserved ambiguity in name only, based on the intent to promote ratification at the cost of clarity. ${ }^{247}$ For example, we have shown that the supposed authority vested in Congress to create or not create lower federal courts was vacuous. Such language was left in place merely to prevent further delays in ratification.

Furthermore, Larry Alexander provides substantial evidence that reliance on original public meaning does not

245 Michael C. Dorf, Truth, Justice, and the American Constitution, 97 Colum. L. REV. 133, 169 (1997).

246 Solum, supra note 42 , at 15-16.

${ }^{247}$ Fish, supra note 129, at 117. 
provide the objectivity that originalists like Solum strive for in the "interpretation" zone. He echoes Fish's intentionalists approach when he argues that there can be no communication without the author intending a particular message. ${ }^{248}$ Original public meaning fails not because it is an untenable intention an author might deploy, but rather because the pursuit of original public meaning substitutes the actual authors' and ratifiers' intents with the intent of a hypothetical Framer or ratifier. ${ }^{249}$ This method also requires manufacturing a hypothetical reader for the document at the time of its ratification. ${ }^{250}$ The normative assumptions inherent in such constructs-their fluency in contemporary English, their social status, their knowledge of political affairs of the day-undermine the supposed objectivity original public meaning proponents offer. ${ }^{251}$ Moreover, Alexander posits that hypothesizing authors invites goal-specific subjectivity, where the scholar deploying original public meaning accepts or rejects available normative assumptions based on argumentative need. 252

This approach does not solve all of originalism's problems. As Fish readily concedes, there are no formulas for determining authorial intent in a given situation. ${ }^{253}$ As he notes, to make an intentionalists argument, "[y]ou just have to sit down and do it, every time." 254 This admission complements our view of originalism's contributions to constitutional interpretation outlined above. Because there is no objective, consistent way to determine authorial intent for any given clause in the Constitution, originalism provides results that are far less useful than its proponents would admit. In the end, "[t]he only thing going for "the intentionalists thesis] is that it is true." 255 Thus,

248 Larry Alexander, Simple-Minded Originalism, in The Challenge of ORIGINALISM: THEORIES OF CONSTITUTIONAL INTERPRETATION 88 (Grant Huscroft \& Bradley W. Miller eds., 2011).

${ }^{249} I d$. at 89, 93 ("[I]f we are to attend to the normative propositions in the Constitution, we should seek the intended meanings of its actual authors...not the intended meanings of any of an indefinite number of possible hypothetical authors.")

$250 \mathrm{Id}$. at 89 .

${ }^{251} I d$.

$252 I d$. at 92 .

253 Fish, supra note 129, at 115.

$254 \mathrm{Id}$.

${ }^{255} I d$. at 116. 
originalism's limited, non-dispositive nature makes it only one among many methods for illuminating the Constitution. Further, the focus on authorial intention opens the door for counter-textual readings of the Constitution that respect compromises not readily apparent on the document's face.

\section{CONCLUSION}

The Supremacy Clause, Article III, Article I, and the State Judges Clause all have been relied upon to support an obligation for state courts to hear federal claims. We have developed another view here that contravenes the prevailing orthodoxy. First, the historical record does not support an antidiscrimination principle inherent in the Supremacy Clause. Founding era debates were primarily directed at controlling overwhelming federal power and the need to preserve state sovereignty, and the Supremacy Clause is thus best understood as a choice-of-law rule that gives preemptive effect to validly enacted, substantive federal laws. Second, neither Article III nor Article I provides Congress with the power to oblige state courts to hear federal claims. Critically, the Madisonian Compromise vested discretion in Congress to control the creation of lower federal courts, but this discretion did not realistically include the option not to create lower federal courts at all. Rather, lower federal courts of some kind were essentially guaranteed in the minds of the Framers so as to properly balance the national and state governments. In short, the Constitution does not restrict the power of states to define the jurisdiction of their courts, even when that power is used to close the state's courts to federal business. 